\title{
Summary of Reported Whale-Vessel Collisions in Alaskan Waters
}

\author{
Janet L. Neilson, ${ }^{1}$ Christine M. Gabriele, ${ }^{1}$ Aleria S. Jensen, ${ }^{2}$ Kaili Jackson, ${ }^{2}$ \\ and Janice M. Straley ${ }^{3}$ \\ ${ }^{1}$ Division of Resource Management, Glacier Bay National Park and Preserve, P.O. Box 140, Gustavus, AK 99826, USA \\ ${ }^{2}$ Office of Protected Resources, National Marine Fisheries Service, P.O. Box 21668, Juneau, AK 99802, USA \\ ${ }^{3}$ Department of Biology, University of Alaska Southeast Sitka Campus, 1332 Seward Avenue, Sitka, AK 99835, USA
}

Correspondence should be addressed to Janet L. Neilson, janet_neilson@nps.gov

Received 6 February 2012; Accepted 26 March 2012

Academic Editor: Frances Gulland

Copyright (C) 2012 Janet L. Neilson et al. This is an open access article distributed under the Creative Commons Attribution License, which permits unrestricted use, distribution, and reproduction in any medium, provided the original work is properly cited.

\begin{abstract}
Here we summarize 108 reported whale-vessel collisions in Alaska from 1978-2011, of which 25 are known to have resulted in the whale's death. We found 89 definite and 19 possible/probable strikes based on standard criteria we created for this study. Most strikes involved humpback whales $(86 \%)$ with six other species documented. Small vessel strikes were most common $(<15 \mathrm{~m}$, $60 \%)$, but medium $(15-79 \mathrm{~m}, 27 \%)$ and large $(\geq 80 \mathrm{~m}, 13 \%)$ vessels also struck whales. Among the 25 mortalities, vessel length was known in seven cases (190-294 m) and vessel speed was known in three cases (12-19 kn). In 36 cases, human injury or property damage resulted from the collision, and at least 15 people were thrown into the water. In 15 cases humpback whales struck anchored or drifting vessels, suggesting the whales did not detect the vessels. Documenting collisions in Alaska will remain challenging due to remoteness and resource limitations. For a better understanding of the factors contributing to lethal collisions, we recommend (1) systematic documentation of collisions, including vessel size and speed; (2) greater efforts to necropsy stranded whales; (3) using experienced teams focused on determining cause of death; (4) using standard criteria for validating collision reports, such as those presented in this paper.
\end{abstract}

\section{Introduction}

Ship strikes are a source of injury and mortality for whales worldwide but documenting these events and their outcomes is a significant challenge. The rate at which whale-vessel collisions occur, the types of vessels involved, and the extent to which they affect particular populations of whales are largely unknown, especially in remote areas such as Alaska. Accurate documentation of whale-vessel collisions is difficult for several reasons, ranging from cases where vessel operators are unaware that collisions should be reported, or operators who do not report for fear of reprisal, to incomplete data gathering on the details surrounding the collision and difficulties inherent in accurately assessing a free-ranging whale's condition following a collision. In addition, a large ship may strike a whale and the crew may be unaware that the collision occurred. Determining that a stranded whale died from a collision is especially difficult in Alaska because of the logistical challenges of performing complete necropsies (e.g., [1]) on stranded animals. These challenges include the remote location of most carcasses, frequent inclement weather, large tides, concerns for human safety when bears are present, limited daylight at some times of the year, and a lack of personnel trained in identifying ship strike injuries.

An overarching challenge in accurately estimating the rate of ship strikes not only in Alaska, but globally, is that there are no universal, standardized criteria for evaluating eyewitness collision reports or stranded whales to determine which cases represent bona fide collisions and which reports should be rejected due to a lack of certainty. Other investigators have compiled accounts of ship strikes regionally and worldwide using variable criteria, terminology, and types of evidence [2-20].

Informed management of whale stocks relies upon accurate estimates of the rate of serious injuries and mortalities from ship strikes. In the United States, the Marine Mammal Protection Act (MMPA) [21] defines a serious injury as any injury that will likely result in mortality. The 
National Oceanic and Atmospheric Administration (NOAA) is responsible for marine mammal stock assessment reports for all species of cetaceans and all species of pinnipeds except walrus, including an estimate of the annual humancaused mortality and serious injury of each stock by source (e.g., commercial fishing, ship strike, etc.). Internationally, the International Whaling Commission (IWC) considers the number of mortalities from ship strikes with estimates of fisheries bycatch in developing recommendations for large whale conservation. The need for a standardized quality control system to validate collision reports has been recognized by the IWC Vessel Strike Data Standardization Group (VSDG), which formed in 2005 to examine the issue of ship strikes with cetaceans. Since 2007, the group has been developing a global ship strike database that aims, among other things, to identify the level of uncertainty associated with individual records based on strandings and eyewitness collision accounts [22]. The IWC database classifies collision reports into six categories (definite ship strike, probable ship strike, possible ship strike, not a ship strike, whale initiated collision, and rejected report); however, these categories do not yet have standardized definitions (D. Mattila, pers. comm.). Each report is reviewed by the VSDG, and an incident is only classified as a "definite ship strike" if all members are unanimous.

At the individual level, the MMPA contains a general prohibition on the "take" of marine mammals, defined as "to harass, hunt, capture, or kill, or attempt to harass, hunt, capture, or kill any marine mammal." NOAA regulations implementing the MMPA further describe the term "take" to include "the negligent or intentional operation of an aircraft or vessel, or the doing of any other negligent or intentional act which results in disturbing or molesting a marine mammal" [23]. In 2001, NOAA implemented regulations in Alaska limiting approaches to humpback whales to minimize disturbance that could adversely affect individual animals and to manage the threat to these animals caused by increasing vessel traffic and a growing whale watch industry in Alaska. These regulations prohibit vessels from approaching within $91 \mathrm{~m}$ (100 yards) of a humpback whale and require vessels to operate at a "slow, safe speed" near humpback whales [24]. This speed is not specified beyond the definition for "safe speed" in 33 US Code 2006, "every vessel shall at all times proceed at a safe speed so that she can take proper and effective action to avoid collision and be stopped within a distance appropriate to the prevailing circumstances and conditions." In addition, since 1979, more protective regulations have existed in Glacier Bay National Park in southeastern Alaska to reduce the risk of humpback whale-vessel collisions and disturbance in park waters. These regulations include limits on the number of vessels allowed to enter Glacier Bay, a $463 \mathrm{~m}$ (one-quarter nautical mile) approach limit to humpback whales, and vessel speed and course restrictions in areas where whales are concentrated [25]. For species other than humpback whales, no specific regulations exist in Alaska, although vessel operators are advised to follow a general marine mammal viewing "Code of Conduct" which recommends remaining at least $91 \mathrm{~m}$ (100 yards) from marine mammals and avoiding excessive speeds. These guidelines are intended to prevent mariners from accidentally harassing or injuring whales in violation of the MMPA and US Endangered Species Act (ESA).

Vessel strikes are a significant concern from other perspectives as well. In Alaska, recovering whale populations and increasing vessel traffic are creating a persistent problem. Collisions are costly and dangerous to humans and they can harm mariners' reputations. From commercial whale watching to subsistence whaling, whales are economically and culturally valuable to Alaska residents and visitors. In addition, one can argue that we have an ethical obligation to address the ship strike issue. For example, in 2007 an injured humpback whale (Megaptera novaeangliae) with a grossly inflated tongue and deformed head was observed alive in southeastern Alaska for three days before dying. A necropsy revealed that the probable cause of death was blunt trauma [26]. From an animal welfare perspective, it is our human responsibility to learn how to mitigate our actions - in this case, prevent collisions-such that whales are not subject to extended periods of suffering before dying from ship strike injuries.

Vessel traffic in Alaska overlaps with 14 whale species known to occur in waters around the state: humpback whale $^{1}$, fin whale (Balaenoptera physalus) ${ }^{1}$, gray whale (Eschrichtius robustus), bowhead whale (Balaena mystice$t u s)^{1}$, minke whale (Balaenoptera acutorostrata), blue whale (Balaenoptera musculus) ${ }^{1}$, sei whale (Balaenoptera borealis) $)^{1}$, North Pacific right whale (Eubalaena japonica $)^{1}$, sperm whale (Physeter macrocephalus) ${ }^{1}$, beluga whale (Delphinapterus leucas) ${ }^{2}$, killer whale (Orcinus orca), Cuvier's beaked whale (Ziphius cavirostris), Stejneger's beaked whale (Mesoplodon stejnegeri), and Baird's beaked whale (Berardius bairdii) $[27,28]$. Population estimates are not available for most of these species in Alaska waters; however, most of the baleen whale stocks are known or thought to be recovering following the end of commercial whaling in the North Pacific in the 1960s and 1970s. For example, stocks of humpback, fin, bowhead, and gray whales are estimated to be increasing at 3-7\% per year [29-32]. A notable exception is the North Pacific right whale, which remains extremely rare with a current population estimate of 31 animals (95\% CL 23-54; [33]) and an unknown population trend [28]. The majority of right whale detections have occurred in the southeastern Bering Sea [33], with a smaller number of detections in the Gulf of Alaska south of Kodiak Island [34]. On the other end of the spectrum, a minimum of 12,000 humpback whales are found in high densities in spring through fall in southeastern Alaska, the eastern Aleutian Islands, along the Bering Sea continental shelf edge and break and in the Gulf of Alaska (primarily near the Shumagin Islands, Kodiak Island and from the Barren Islands through Prince William Sound) $[28,31]$.

The whale strike risk for various vessel types relies on a number of factors, including the number of vessels on the water and their geographic overlap with each whale species. Much of the vessel traffic in Alaskan waters is highly seasonal and concentrated in coastal areas of southeastern and south central Alaska during the summer months, where private 
and commercial recreational vessels (e.g., charter vessels, commercial whale watch vessels, tour boats, and cruise ships) are prevalent. Other types of vessel traffic in Alaskan waters are more likely to occur year-round and/or over broader geographic areas, including both near shore and offshore waters (e.g., commercial fishing vessels, freighters/tankers, passenger ferries, etc.), where they may overlap with a variety of near shore and offshore species [28]. In general, there is less vessel traffic off western and northern Alaska compared to other parts of the state, although these trends are already changing with climate change-driven decreases in sea ice in the Bering, Chukchi, and Beaufort seas.

Vessel speed and size appear to be important factors in predicting whale-vessel collisions and their outcomes. For example, the probability of a cruise ship having a close encounter with a humpback whale increases with the speed of the ship (especially at speeds $>11.8 \mathrm{kn}$ ) [35], and Silber et al. [36] demonstrated that during close encounters, reduced ship speeds may reduce the probability of a collision. Further evidence comes from an analysis of worldwide collision records with large whales, in which Laist et al. [8] found that most lethal and severe injuries involve ships traveling $14 \mathrm{kn}$ or faster and ships $80 \mathrm{~m}$ or longer. Likewise, Vanderlaan and Taggart [37] analyzed collision records, modeled the probability of lethal injury to a large whale based on vessel speed, and concluded that the chances of a lethal injury exceed $50 \%$ at speeds higher than $11.8 \mathrm{kn}$.

The summary reported here represents the most comprehensive compilation of whale-vessel collision records in Alaska that has yet been assembled [38, 39]. All records included here were evaluated using our newly developed standardized system for classifying collision records (witnessed at sea or based on strandings) into four confidence categories (definite strike, probable strike, possible strike and rejected report). Our primary goals were to (1) summarize the circumstances surrounding whale-collisions in Alaska, (2) recommend ways to improve data collection and validation, and (3) identify measures to help reduce collision risk.

\section{Methods}

Our study area included all waters of Alaska. We considered records that involved any species of cetacean within $370 \mathrm{~km}$ (200 nautical miles) of Alaska except for dolphins and porpoises. Reports of whale-vessel collisions originated from a variety of sources, including NOAA, the US Coast Guard (USCG), vessel owners, tour operators, the media, and anecdotal accounts. These reports were collected opportunistically by the National Park Service (NPS) and the University of Alaska Southeast (UAS) since 1978 and systematically by NOAA since the Alaska Marine Mammal Stranding Network was formed in 1985 [40]. We evaluated records where the whale species was uncertain or unknown on a case-by-case basis. If the species was reported as uncertain but "likely" or "probable" species X and the report was plausible given the seasonal and geographic distribution of species $\mathrm{X}$, then we attributed the report to species X. We counted all other reports where the species was unknown as "unidentified species." We rejected reports when there was insufficient information to verify that an actual strike occurred.

To analyze seasonal occurrence in collisions, we assigned a month to each record based on when the strike occurred or the carcass was found. Similarly, we assigned a year to each record based on when the strike occurred or when the carcass was found. We assigned one record from the "late 1980 s" to the year 1989 . We used linear regression to examine the trend in the number of reports over time and log-linear regression to estimate the average annual rate of increase in reports.

2.1. Ship Strike Confidence Categories. The reports were based on (1) collisions witnessed at sea and (2) strandings in which a dead whale was found with evidence of collision injuries. We did not consider reports of whales striking vessels after being shot or harpooned because these collisions are atypical and including them in our analysis would not contribute to our understanding of typical whale-vessel collisions. We error-checked each record against all available documentation and entered the records into a relational database. To avoid potential duplicate reports, we did not include sightings of live whales with visible propeller scars unless the collision that caused the propeller injuries was witnessed. We assigned each record to one of four confidence categories: definite ship strike, probable ship strike, possible ship strike, or rejected report (Table 1).

2.2. Sex and Age Class of Struck Whales. We determined the sex of stranded whales from necropsy reports. It was not possible to determine the sex of live animals; however, in two cases, we knew that individually identified humpback whales were female because we had documented them in previous years with calves (NPS and UAS unpublished data). In one case, we knew that an individually identified humpback whale was male based on genetic analysis (NPS and UAS unpublished data).

We assigned the whale in each report to one of the following age classes: calf, juvenile, adult, or unknown. We based most of our assessments on empirical measurements of dead whales' lengths using guidelines from the scientific literature for each species [41-45]. For humpback whales, we defined calves as $<1$ year old and juveniles as whales $\geq 1$ year old but $<5$ years old [46]. We determined that one dead individually identified humpback whale was an adult based on its $\geq 5$-year sighting history (UAS unpublished data). We used the following guidelines to classify dead humpback whales based on body length: calves are typically $4-4.5 \mathrm{~m}$ in length at birth $[47,48]$, grow to $7-8 \mathrm{~m}$ in length by late summer [49], attain body lengths of $8-10 \mathrm{~m}$ at independence [48], and reach sexual maturity (adulthood) at approximately $12 \mathrm{~m}$ in length [50]. We classified an $8.2 \mathrm{~m}$ humpback whale that was found dead on March 13, 2005 as a juvenile, even though its length fell within the typical range for calves because it was too big to be a calf based on the date it was found. Also, anisakid nematode parasites were found in the whale's small intestines, indicating that it was feeding on fish, not milk ([51]; F. Gulland, pers. comm.). 
TABLE 1: Ship strike confidence categories.

\begin{tabular}{|c|c|}
\hline Confidence category & Definition \\
\hline \multirow{16}{*}{ Definite strike } & There is evidence that a strike occurred beyond a reasonable doubt. For example: \\
\hline & $\begin{array}{l}\text { Strike was witnessed by the vessel operator/crew or by the operator/crew of a } \\
\text { nearby vessel }\end{array}$ \\
\hline & or \\
\hline & $\begin{array}{l}\text { Strike was not witnessed but whale has massive blunt impact trauma (defined by } \\
\text { disarticulated vertebrae or fractures of one or more heavy bones including skull, } \\
\text { mandible, scapula, vertebra or adult rib, and a focal area of severe hemorrhaging) }\end{array}$ \\
\hline & or \\
\hline & $\begin{array}{l}\text { Strike was not witnessed but carcass has apparent propeller wounds }{ }^{1} \text { (i.e., deep } \\
\text { parallel slashes or cuts into the blubber) on the dorsal aspect }\end{array}$ \\
\hline & or \\
\hline & $\begin{array}{l}\text { Strike was not witnessed but carcass has propeller wounds on the ventral and/or } \\
\text { lateral aspect which a necropsy confirms were produced ante mortem }\end{array}$ \\
\hline & or \\
\hline & $\begin{array}{l}\text { Strike was not witnessed but carcass has an amputated appendage (e.g., fluke or } \\
\text { flipper) which a necropsy confirms occurred ante mortem due to a sudden and } \\
\text { traumatic laceration (versus an entanglement injury causing a slow, ischemic loss of } \\
\text { the appendage) }\end{array}$ \\
\hline & or \\
\hline & $\begin{array}{l}\text { Strike was not witnessed but evidence of a collision was found on the vessel (e.g., } \\
\text { whale skin or tissue) }\end{array}$ \\
\hline & or \\
\hline & Whale was found on the bow of a ship \\
\hline & 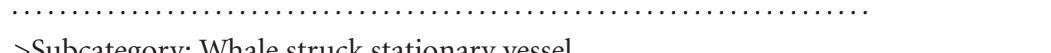 \\
\hline & Vessel was stationary at the time of the collision (i.e., anchored or drifting) ${ }^{2}$ \\
\hline \multirow{13}{*}{ Probable strike } & The report is likely to be true; having more evidence for than against, but some \\
\hline & evidence is lacking. For example: \\
\hline & Vessel operator/crew or operator/crew of a nearby vessel believes that a strike \\
\hline & occurred but cannot confirm the strike with absolute certainty \\
\hline & or \\
\hline & Strike was not witnessed, and the whale is a calf with smaller broken bones (e.g., \\
\hline & ribs) that could have been fractured by another animal rather than by a vessel \\
\hline & or \\
\hline & Strike was not witnessed and the whale shows partial evidence of a collision other \\
\hline & than as defined under definite strike. For example: \\
\hline & (i) Whale has a focal area of severe hemorrhaging but no known broken bones; \\
\hline & $\begin{array}{l}\text { therefore, it is possible the trauma was caused by another animal rather than by a } \\
\text { vessel; }\end{array}$ \\
\hline & $\begin{array}{l}\text { (ii) Carcass has propeller wounds on the ventral and/or lateral aspect; however, the } \\
\text { necropsy is not able to determine if they were produced ante mortem }\end{array}$ \\
\hline \multirow{7}{*}{ Possible strike } & The report may be true; however, a majority of evidence is lacking. For example: \\
\hline & Vessel operator/crew or operator/crew of a nearby vessel believes that a strike may \\
\hline & have occurred but there is significant uncertainty \\
\hline & or \\
\hline & Vessel operator/crew or operator/crew of a nearby vessel believes that a strike \\
\hline & occurred, while the vessel operator/crew or operator/crew of a nearby vessel believes \\
\hline & that a strike did not occur \\
\hline
\end{tabular}


TABle 1: Continued.

\begin{tabular}{|c|c|}
\hline \multirow[t]{4}{*}{ Confidence category } & Definition \\
\hline & or \\
\hline & Strike was not witnessed, and the whale shows partial evidence of a collision other \\
\hline & $\begin{array}{l}\text { than as defined under definite or probable strike, such as damage to an appendage } \\
\text { or skin, but the necropsy is incomplete or there is no close examination of the } \\
\text { whale (e.g., whale is viewed from a distance only) }\end{array}$ \\
\hline \multirow{8}{*}{ Rejected report } & The report is not credible. For example: \\
\hline & Third-hand report \\
\hline & or \\
\hline & No credible eyewitnesses ${ }^{3}$ \\
\hline & or \\
\hline & Lacking sufficient detail or documentation to be credible \\
\hline & or \\
\hline & Necropsy determines an alternate cause of death \\
\hline
\end{tabular}

\footnotetext{
${ }^{1}$ We only included whales with propeller wounds where there was evidence that the strike occurred in Alaska (i.e., the propeller wounds had to be from a strike that was witnessed and/or the propeller wounds had to be fresh (bleeding) or assessed to be fresh by a trained observer.)

${ }^{2}$ We counted collisions involving kayaks and canoes under this subcategory unless the kayak/canoe was known to be traveling at $>0 \mathrm{kn}$.

${ }^{3}$ The credibility of the eyewitness(es) was assessed on a case-by-case basis. The most credible eyewitness is someone who had "something to lose" in reporting the collision (e.g., the captain and/or the crew of the vessel that struck the whale) because it is presumed they would not risk reporting the collision if it had not occurred. The least credible eyewitness is a passenger on a commercial vessel (e.g., whale watch vessel, cruise ship, etc.) who reports a collision, but there is no supporting evidence (photos, observation of wound, blood, etc.) or other eyewitnesses. In these cases, the report was rejected unless the passenger was an experienced observer and/or additional eyewitnesses were available to corroborate the report (assessed on a case-by-case basis).
}

Most observations of live whales were classified as age class unknown; however, we classified two live sightings of humpback whales made by knowledgeable observers as calves based on their close, consistent affiliation with an adult whale, presumed to be the mother (after [52]; J. Neilson, pers. obs.; commercial whale watch captain, pers. obs.). Similarly, we classified one live sighting of a humpback whale as a juvenile based on the animal's very small body size (J. Neilson, pers. obs.). We determined that three live individually identified humpback whales were adults based on their $\geq 5$ year sighting histories (NPS, UAS, and Kewalo Basin Marine Mammal Laboratory unpublished data).

2.3. Vessel Characteristics. We assigned each report to one of the following vessel categories: private recreational, nonmotorized recreational (e.g., kayaks and canoes), commercial recreational (e.g., charter vessels, tour boats, and commercial whale watch vessels), cruise ship, cargo (e.g., oil tankers, container ships, and landing craft), commercial fishing, research, USCG cutter, state ferry, or unknown. After Laist et al. [8], we classified vessel lengths as small $(<15 \mathrm{~m})$, medium $(15-79 \mathrm{~m})$, large $(\geq 80 \mathrm{~m})$, or unknown. We searched the USCG's Port State Information Exchange (PSIX) online database [53] and commercial vessel operator's websites to fill in missing vessel lengths when the vessel name was reported.

We evaluated the vessel's activity prior to the collision by assigning each record to one of the following categories: anchored or drifting with engine off, slow travel $(<12 \mathrm{kn})$, fast travel $(\geq 12 \mathrm{kn})$, travel at unknown speed, whale watching, intentionally approaching whales (e.g., whale research), intentionally ramming whales, commercial longline fishing and unknown. Similarly, we evaluated the vessel's activity at the time of the collision by assigning each record to one of the following categories: anchored or drifting silently, slow travel $(<12 \mathrm{kn})$, fast travel $(\geq 12 \mathrm{kn})$, decelerating from fast travel, decelerating from unknown speed, travel at unknown speed, and unknown. We classified vessel speed at the time of the collision as anchored or drifting, $1-11 \mathrm{kn}$, $\geq 12 \mathrm{kn}$, or unknown. Separating vessel activity into these two components allowed us to link particular vessel behavior with collision risk and to assess the outcome of the collision with some knowledge of the force with which the whale was struck.

2.4. Fate of Whales. We evaluated the fate of the whale after the collision by assigning each report to one of the following categories: minor injury (presumably not life threateninge.g., no blood reported in water), severe injury (potentially life threatening-e.g., blood reported in water), dead, or unknown. We described dead whales' injuries as unknown, blunt trauma, or sharp trauma $[54,55]$.

2.5. Human Toll and Property Damage from Collisions. We assessed the human toll and/or property damage resulting from each collision by counting the number of reports in which passengers onboard the vessel were knocked down, injured, or thrown into the water. To avoid double-counting reports, passengers who were knocked down and injured were only counted as injured. However, passengers who were injured and thrown into the water were counted in both categories because we were interested in the frequency of both of these two outcomes. We also counted the number of reports in which there was significant damage to the vessel or the vessel sank. We defined significant damage as that which required repairs for continued use of the vessel. 
2.6. Collision Hotspots. We used the kernel density analysis tool in ArcGIS 10.0 (ESRI Inc., Redlands, CA, USA) to identify potential high risk areas for whale-vessel collisions in southeastern Alaska. Only collisions that were witnessed at sea were included in the analysis. Dead whales where no collision was reported (including bow-caught whales where the collision was not witnessed), were excluded because the location where they were found may not be the same as the location where they were struck [8]. We set the output raster cell size to be $100 \mathrm{~m}$ and the search radius (kernel bandwidth) to be $20 \mathrm{~km}$. For clarity, raster cell values representing extremely low collision densities $(<0.0025$ collisions per $\mathrm{km}^{2}$ ) were excluded from the map. The remaining raster cell values (range $0.0025-0.0211$ collisions per $\mathrm{km}^{2}$ ) were manually divided into 32 equal classes and displayed in colors ranging from yellow (moderate collision risk) to red (higher collision risk).

\section{Results}

We verified 108 and rejected 11 reports of whale-vessel collisions in Alaska waters between 1978 and 2011. The 11 rejected reports were not included in further analyses. Most strikes $(n=93,86 \%)$ involved humpback whales, although six other species were documented (Table 2, Appendix 1 in supplementary material) (Supplementary Material will be available online at doi:10.1155/2012/106282). In eight reports $(7 \%)$ the species was uncertain; however, we assigned seven of these records to humpback whales and one record to a Cuvier's beaked whale. In one report, a pair of humpback whales, thought to be a cow and calf, were involved in a collision but it was unknown which animal was hit; we counted this as one strike, not two, with the sex and age class of the struck whale unknown.

We found a significant increase in the number of reports over time between 1978 and 2011 (regression, $r^{2}=0.6999$, df $=32, P<0.001)$. Most strikes $(n=98,91 \%)$ occurred in May through September and there were no reports from December or January. The majority of strikes $(n=82$, $76 \%$ ) were reported in southeastern Alaska (Figure 1), where the number of humpback whale collisions increased 5.8\% annually from 1978 to 2011.

Most reports $(n=86,80 \%)$ were based on collisions witnessed at sea, while the remaining 22 reports (20\%) were based on dead whales where no collision was reported. The geographic location of the 22 dead whales and the dates when they were found did not correlate with any of the witnessed collisions; therefore, we do not believe we double-counted any of these reports. Three of the collisions witnessed at sea are known to have resulted in mortalities, for a total of 25 dead whales.

3.1. Ship Strike Confidence Categories. The majority of reports $(n=89,82 \%)$ were assessed to be definite strikes and in $15(17 \%)$ of these cases, a whale struck a stationary vessel. Seventy-nine $(89 \%)$ of the 89 definite strikes were based on witnessed collisions, and 10 reports $(11 \%)$ were based on dead whales where no collision was reported. Two $(22 \%)$ of the nine probable strikes were based on witnessed collisions, and seven reports (78\%) were based on dead whales where no collision was reported. Five (50\%) of the 10 possible strikes were based on witnessed collisions, and five reports (50\%) were based on dead whales where no collision was reported.

Two of the nine probable strikes were thoroughly investigated, but seven reports were not and may have been upgraded to definite strikes with more complete followup (e.g., complete necropsies). In one of the two probable strikes that were witnessed, a dead humpback whale washed ashore within $3 \mathrm{~km}$ of where a $190 \mathrm{~m}$ cruise ship transiting at an unknown speed reported striking what they believed to be a whale three days earlier; however, there was no close examination of the whale [56]. Similarly, three of the 10 possible strikes were thoroughly investigated, but seven reports were not and may have been upgraded to definite strikes with more complete follow-up. For example, two of the vessel operators involved in witnessed collisions were not interviewed, and four of the five dead whales were not necropsied or examined closely. The fifth dead whale was necropsied; however, the necropsy did not get down to bone to look for fractures diagnostic of a collision.

3.2. Sex and Age Class of Struck Whales. Nine of the 25 dead whales were female, nine were male, and seven were of unknown sex (Table 3 ). In addition, we documented three live individually identified humpback whales (two females and one male) for a total, of 21 whales of known sex (10 males and 11 females).

There were 25 whales of known age involved in collisions: seven calves, seven juveniles, and 11 adults. Five dead whales were calves, six were juveniles, eight were adults, and six were of unknown age (Table 3). In addition, six humpback whales in witnessed collisions were assigned to age classes (two calves, one juvenile, and three adults). Six adult female humpback whales are known to have died from collisions and four of these mortalities occurred in southeastern Alaska between 2001 and 2011.

\subsection{Vessel Characteristics}

3.3.1. Vessel Type. In 19 cases, the type of vessel involved in the collision was unknown (18 were dead whales where no collision was reported, but one was a witnessed collision where the type of vessel was not recorded.) In the 89 cases where the vessel type was known, $35 \%(n=31)$ were private recreational, $35 \%(n=31)$ were commercial recreational, $8 \%(n=7)$ were cruise ships, $7 \%(n=6)$ were commercial fishing vessels, $4 \%(n=4)$ were USCG cutters, $3 \%(n=3)$ were cargo, $3 \%(n=3)$ were nonmotorized recreational, $3 \%$ $(n=3)$ were research, and $1 \%(n=1)$ was a state ferry. The three cargo vessels were a 254-m oil tanker, a $216-\mathrm{m}$ container ship, and a 10-m landing craft. The seven cases where the vessel type was known and the whale died involved large cruise ships $(n=5)$ or cargo vessels $(n=2$; one container ship and one oil tanker). All three non-motorized recreational vessel strikes occurred in Glacier Bay.

3.3.2. Vessel Length. In 44 reports (41\%) vessel length was not reported; however, in 18 of these cases we were able to 
TABLE 2: Summary of whale-vessel collisions reported in Alaska 1978-2011. Rejected reports are not included.

\begin{tabular}{llcccc}
\hline Species & Definite strike & $\begin{array}{c}\text { Confidence category } \\
\text { Probable strike }\end{array}$ & Possible strike & Total & Number of known dead \\
\hline Humpback whale & 78 & 8 & 7 & $93(86.1 \%)$ & 17 \\
Fin whale & 3 & & & $3(2.8 \%)$ & 2 \\
Gray whale & 1 & & & $1(0.9 \%)$ & 1 \\
Sperm whale & 1 & 1 & 1 & $2(1.9 \%)$ & 2 \\
Cuvier's beaked whale & & & 1 & $1(0.9 \%)$ & 1 \\
Stejneger's beaked whale & & & 1 & $1(0.9 \%)$ & 1 \\
Beluga whale & 6 & & & $6(5.6 \%)$ & 1 \\
Unidentified whale & $89(82.4 \%)$ & $9(8.3 \%)$ & $10(9.3 \%)$ & $(100 \%)$ & 25 \\
\hline Total & & & & \\
\hline
\end{tabular}

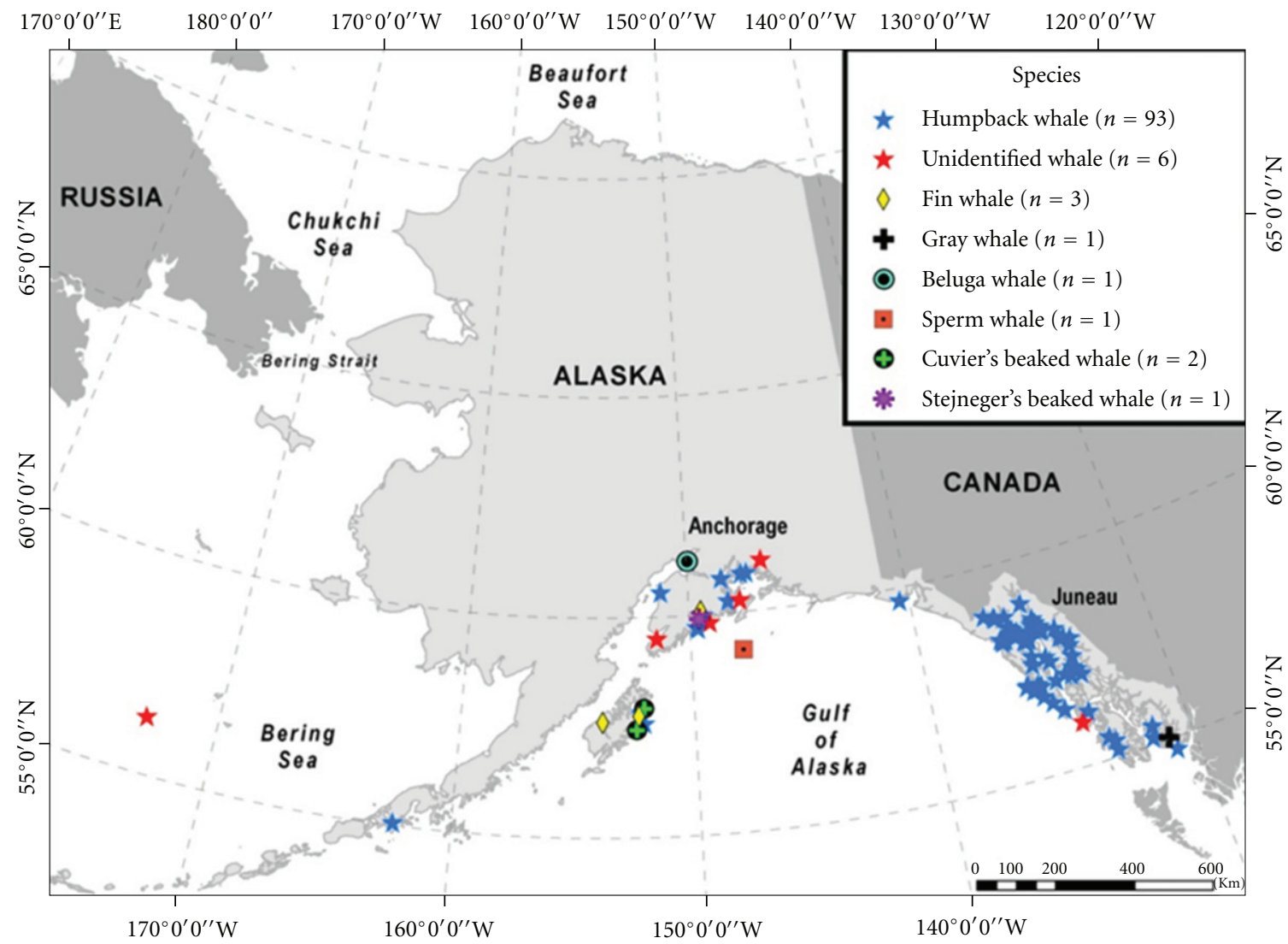

Figure 1: Location of whale-vessel collision reports in Alaska by species 1978-2011 $(n=108)$. Rejected reports are not included.

infer the vessel's length category based on the vessel type ( $n=$ 4 , e.g., kayak and Zodiac) or look up the vessel length online using the vessel's name $(n=14)$. This left 26 reports where vessel length was unknown. Eighteen of these cases were dead whales where no collision was reported; however, eight were witnessed collisions, of which five were reported to and/or investigated by federal law enforcement officials.
In the 82 reports where vessel length was known (range 5-294 m), small $(<15 \mathrm{~m})$ vessels were the most commonly reported $(n=49,60 \%)$, followed by medium $(15-79 \mathrm{~m})$ vessels $(n=22,27 \%)$, and large $(\geq 80 \mathrm{~m})$ vessels $(n=11$, $13 \%)$. The difference in the number of reports in each vessel length category is significant (chi-square test for goodness of fit, $\left.\chi^{2}=27.976, \mathrm{df}=2, P<0.001\right)$. 
TABLe 3: Sex and age classes of the 25 whales known to have been killed by vessels.

\begin{tabular}{|c|c|c|c|c|c|c|c|c|c|}
\hline & & Male & & & Female & & & ex unknown & \\
\hline Species & Calf & Juvenile & Adult & Calf & Juvenile & Adult & Adult & Age class unknown & Total \\
\hline Humpback whale & 4 & 2 & 1 & 1 & & 6 & & 3 & 17 \\
\hline Fin whale & & 1 & & & 1 & & & & 2 \\
\hline Gray whale & & & & & 1 & & & & 1 \\
\hline \multicolumn{10}{|l|}{ Sperm whale } \\
\hline Cuvier's beaked whale & & 1 & & & & & & 1 & 2 \\
\hline Stejneger's beaked whale & & & & & & & 1 & & 1 \\
\hline Beluga whale & & & & & & & & 1 & 1 \\
\hline Unidentified whale & & & & & & & & 1 & 1 \\
\hline Total & 4 & 4 & 1 & 1 & 2 & 6 & 1 & 6 & 25 \\
\hline
\end{tabular}

3.3.3. Vessel Activity Prior to Collision. In 18 reports (17\%) the vessel's activity prior to the collision was unknown or not reported. In the 90 reports where the vessel's activity was known, $44 \%(n=40)$ were engaged in fast travel, $16 \%$ $(n=14)$ were anchored or drifting silently, $14 \%(n=13)$ were engaged in slow travel, $12 \%(n=11)$ were traveling at an unknown speed, $7 \%(n=6)$ were whale watching, $3 \%(n=3)$ were intentionally approaching whales, $2 \%$ $(n=2)$ were intentionally ramming whales, and $1 \%(n=1)$ were commercial fishing. Note that whale watching vessels that were traveling prior to the collision were classified under one of the traveling vessel activity categories. The difference in the number of reports in each vessel activity category is significant (chi-square test for goodness of fit, $\left.\chi^{2}=99.867, \mathrm{df}=7, P<0.001\right)$.

3.3.4. Vessel Activity at Time of Collision. In 19 reports (18\%) the vessel's activity at the time of the collision was unknown or not reported. In the 89 reports where the vessel's activity was known, 33 (37\%) were engaged in fast travel, $19(21 \%)$ were engaged in slow travel, $15(17 \%)$ were anchored or drifting silently, $12(13 \%)$ were traveling at an unknown speed, $9(10 \%)$ were decelerating from fast travel, and one (1\%) was decelerating from slow travel. The 10 vessels that reported decelerating did so in response to seeing the whale just prior to the collision, thus in some cases, their speed at the time of the collision (below) is lower (i.e., $1-11 \mathrm{kn}$ versus $\geq 12 \mathrm{kn}$ ). The difference in the number of reports in each vessel activity category is significant (chi-square test for goodness of fit, $\chi^{2}=39.157$, df $=5, P<0.001$ ). All 15 of the cases where a whale struck a stationary vessel involved humpback whales hitting vessels that were anchored or drifting with their engine off.

3.3.5. Vessel Speed at Time of Collision. In 47 reports (44\%) vessel speed at the time of the collision was unknown or not reported; however, in 14 of these cases we were able to infer the vessel's speed based on other information in the report (e.g., "sailboat under power" was classified as 1$11 \mathrm{kn})$. This resulted in 75 reports (69\%) where vessel speed was known (range 0-35 kn), with vessels, traveling at $\geq 12 \mathrm{kn}$ the most commonly reported ( $n=37,49 \%$ ), followed by vessels traveling at $1-11 \mathrm{kn}(n=23,31 \%)$, and anchored or drifting vessels ( $n=15,20 \%)$. The difference in the number of reports in each vessel speed category is significant (chisquare test for goodness of fit, $\chi^{2}=9.92$, df $=2, P<0.05$ ).

Twenty-two of the 33 cases $(67 \%)$ where vessel speed was unknown were dead whales where no collision was reported; however, 11 (33\%) were witnessed collisions in which speed was not recorded. The maximum speed reported $(35 \mathrm{kn})$ was a $10 \mathrm{~m}$ jet boat whose operator intentionally rammed a pair of humpback whales thought to be a cow and calf [57].

3.4. Fate of Whales. In most cases $(n=78,72 \%)$, the fate of the whale following the collision was unknown, but 25 cases (23\%) were known mortalities, and in five cases (5\%) the whale was documented alive in subsequent months or years using individual identification techniques (NPS and UAS unpublished data).

3.4.1. Minor Injuries. In 11 cases (10\%) the whale was observed with either a presumably minor injury or no visible injuries (all were humpback whales). Five of these whales are known to have survived; however, the fate of the other six whales is unknown. The five surviving whales (one calf, three adults, and one age unknown) were hit by vessels $<20 \mathrm{~m}$ in length (range $7-19.8 \mathrm{~m})$ traveling at $5 \mathrm{kn}(n=1), 10 \mathrm{kn}$ $(n=2), 25 \mathrm{kn}(n=1)$, and an unknown speed $(n=1)$. The latter vessel was whale watching and was therefore likely traveling at $1-11 \mathrm{kn}$. Three of the whales had blunt trauma injuries after being struck by the bows of vessels and two had sharp trauma injuries from propellers. The collision that occurred at $25 \mathrm{kn}$ was reported in 2008 by the captain of a $10 \mathrm{~m}$ aluminium tour boat after he struck a humpback whale as the whale came up to breathe [58]. The captain believed that the whale he hit was an individual with a uniquely marked dorsal fin that was well known to tour boat captains in the area. The speed of the vessel decreased approximately 3-4 kn after the strike, and he did not see the whale come up again, but it is unknown how long the vessel stayed on scene. Later that day, this uniquely marked adult whale was documented behaving normally and lunge feeding nearby (NOAA unpublished data), and it was observed as recently as 2011 with no visible injuries (NPS unpublished data). The calf that was struck was documented alive with its mother 75 days after being hit by an $18 \mathrm{~m}$ commercial fishing vessel 
transiting at $10 \mathrm{kn}$ (NOAA unpublished data). The other three whales that are known to have survived have been documented for a minimum of six years post-collision (NPS unpublished data).

3.4.2. Severe Injuries. In five cases $(5 \%)$ the whale was observed after the collision with a severe injury (three humpback whales and two unidentified large whales); however, the fate of these whales is unknown. In four of these cases, blood was reported in the water. Three of these whales had sharp trauma injuries from propellers, while the type of injury sustained by the fourth whale was unknown. In the fifth case, a humpback whale punched a $1.5 \mathrm{~m}$ hole through the hull of an anchored $22 \mathrm{~m}$ wooden sailboat, sinking the vessel and leaving six plates of baleen measuring approximately $0.3 \mathrm{~m}$ in length held together by torn flesh inside the splintered hull.

3.4.3. Mortalities. In 25 cases $(23 \%)$ the whale is known to have died, but vessel length and speed were known in only three of these cases. Two of the 86 collisions witnessed at sea that are known to have caused mortalities (both were adult humpback whales) involved $232 \mathrm{~m}$ and $243 \mathrm{~m}$ cruise ships traveling $14 \mathrm{kn}$ and $19 \mathrm{kn}$, respectively. In a third case, a dead humpback whale was found on the bow of a $216 \mathrm{~m}$ container ship, and the vessel's speed at the time of the collision is unknown; however, its typical transit speed was 12-19 kn. Statewide, humpback whale vessel-strike mortalities peaked in $2010(n=4)$ and we found an increasing trend in the number of humpback whales killed between 1978 and 2011 (regression, $r^{2}=0.1193$, $\mathrm{df}=32, P<0.05$ ).

Thirteen (52\%) of the 25 dead whales were first reported floating: five were towed to shore for examination, five are known to have washed ashore on their own, and three were not towed and floated away. Seven $(28 \%)$ of the dead whales were first reported beach-cast. Five of the dead whales (20\%) were caught on the bulbous bows of large ships (three humpback whales, one fin whale and one unidentified large baleen whale in 2009 that appeared to be a fin, blue, or sei whale). One of the humpback whales slipped off a $243 \mathrm{~m}$ cruise ship's bow and sank when the ship slowed down, the other four bow-caught whales remained pinned to the ships' bows ( $288 \mathrm{~m}$ cruise ship, $294 \mathrm{~m}$ cruise ship, $254 \mathrm{~m}$ oil tanker, and $216 \mathrm{~m}$ container ship) until they came into port or stopped. The state of decomposition and point of collision impact on two of the whales is unknown. However, the fin whale and two of the humpback whale carcasses were fresh (not bloated) and appeared to have been struck on the dorsal side of their bodies, indicating that the whales were alive when they were hit $[9,54]$. This is inferred because most large whales (except right and bowhead whales) sink when they die and then rise to the surface, ventral side up, as decomposition gases inflate the abdomen (assuming the abdominal cavity is intact and the carcass is in relatively shallow water) [18, $59,60]$. Depending on blubber thickness, some whales may float immediately upon death; in these cases, they typically will float ventral side up within approximately 24 hours as decomposition gases inflate the abdomen (F. Gulland, pers. comm.). Therefore, collision injuries on the dorsal side of a
TABLe 4: Types of injuries sustained by the 25 whales known to have been killed by vessels.

\begin{tabular}{llcc}
\hline Species & $\begin{array}{l}\text { Blunt } \\
\text { trauma }\end{array}$ & $\begin{array}{c}\text { Sharp } \\
\text { trauma }\end{array}$ & $\begin{array}{c}\text { Unknown } \\
\text { injuries }\end{array}$ \\
\hline $\begin{array}{l}\text { Humpback whale } \\
\text { Fin whale }\end{array}$ & 12 & 2 & 3 \\
$\begin{array}{l}\text { Cuvier's beaked whale } \\
\text { Stejneger's beaked whale }\end{array}$ & 1 & 1 & \\
$\begin{array}{l}\text { Gray whale } \\
\text { Beluga whale }\end{array}$ & 1 & 1 & \\
Unidentified whale & & & 1 \\
\hline Total & $16(64 \%)$ & $5(20 \%)$ & $4(16 \%)$ \\
\hline
\end{tabular}

whale provide indirect evidence that the whale was alive (or extremely recently dead) when it was struck, otherwise the point of collision impact would be expected on the whale's ventral or lateral side ([54], F. Gulland, pers. comm.).

The first whale necropsy conducted in Alaska with a veterinarian trained in assessing ship strike injuries occurred in 2001. Since then, numerous veterinarians, stranding team members and other personnel have gained experience in assessing ship strike injuries and 13 more necropsies have found evidence that whales died from collisions. However, six of these necropsies were incomplete, meaning that the carcass was not flensed down to the bone to look for fractures. In several cases, the necropsy team ran out of time as the incoming tide covered the carcass. Overall, 11 humpback whales, two fin whales, and one Cuvier's beaked whale with ship strike injuries have been necropsied since 2001.

Most of the 25 dead whales $(n=16,64 \%)$ had blunt trauma injuries, five (20\%) had sharp trauma injuries, and four $(16 \%)$ had unknown injuries because they were not necropsied (Table 4); however, at least three (two humpback whales and one unidentified large baleen whale that appeared to be a fin, blue, or sei whale) likely suffered from blunt trauma because they were found pinned to ships' bows. The fourth whale stranded in 1978 after a cruise ship reported striking what they believed to be a whale; however, there was no close examination of this humpback whale, and it is unknown if the ship's bow or propeller(s) struck the whale.

The necropsy of an adult female humpback whale found on the bow of a $288 \mathrm{~m}$ cruise ship in 2010 revealed a potentially complicated history [61]. A necropsy was conducted, and both gross and internal assessments of the carcass were made; however, the necropsy was limited by an incoming tide. Though it was not possible to strip the carcass entirely to the bone, the animal was found to have a sharp trauma injury (amputated pectoral flipper cut cleanly at $0.8 \mathrm{~m}$ in diameter), acute degenerative myopathy in several muscle tissues (indicating severe ante mortem stress and muscle exertion), and a large area of missing inframandibular tissue, indicating that the whale may have been fed on by killer whales. Elevated saxitoxin levels were also detected, which could have caused the whale to behave abnormally, making it more vulnerable to being struck. It has been proposed 
that the whale may have been struck initially by a different large vessel, shearing off the pectoral fin and causing debility and/or death, followed by possible predation by killer whales, and eventual postmortem entrapment on the bow of the cruise ship. However, in initial photos of the carcass on the ship's bow, the whale does not appear to be bloated and the point of collision impact is on the dorsal thorax, indicating that the whale may have been alive when it was struck. We include the details of this particular report to illustrate the complexities involved in piecing together case histories and determining cause of death.

\subsection{Human Toll and Property Damage from Collisions.} In 37 reports $(34 \%)$ the passengers and vessel were not affected by the collision, in 36 reports (33\%) there was some kind of human toll and/or property damage resulting from the collision, and in 35 reports (32\%) the outcome of the collision for the passengers and vessel is unknown. There were 19 reports in which passengers were knocked down (affecting a minimum of 41 people), 10 reports in which passengers were injured (affecting a minimum of 18 people), 9 reports in which passengers were thrown into the water (affecting a minimum of 15 people), 20 reports of significant property damage, and three reports of private recreational vessels sinking. Two of the vessels that sank (a $10 \mathrm{~m}$ fiberglass sailboat and a $22 \mathrm{~m}$ wooden sailboat) were anchored or drifting with their engine off when they were rammed by humpback whales. The third case involved a $8 \mathrm{~m}$ polyethylene powerboat that sank after striking an unidentified large whale while transiting at $19 \mathrm{kn}$.

3.6. Collision Hotspots. We identified several high risk areas for whale-vessel collisions in southeastern Alaska (Figure 2). All of the high risk areas were located in the northern portion of southeastern Alaska. The areas with the highest collision densities centered around Point Adolphus in Icy Strait and around North Pass in lower Lynn Canal, both popular whale watching destinations. Medium-risk areas centered around the Inian Islands in Cross Sound and in Sitka Sound. Other areas where we identified a collision risk included eastern Icy Strait near Hoonah, the lower West Arm of Glacier Bay, upper Stephens Passage, and eastern Frederick Sound.

\section{Discussion}

The great majority of ship strikes in Alaska occur with humpback whales in southeastern Alaska. This area is primarily comprised of protected waters and supports a genetically distinct feeding aggregation of 3,000-5,000 humpback whales [31]. The number of humpback whale collisions detected in this region increased by $5.8 \%$ annually from 1978 to 2011, which closely matches the $6.8 \%$ annual growth rate of the humpback whale population in southeastern Alaska between 1986 and 2008 [62]. Although the problem at present may not be resulting in population level impacts, a collision with a large whale is considered a "take" under the MMPA and is therefore a cause for concern, as are other considerations such as human safety. Our results showing an increase over time in whale and vessel collisions are susceptible to several biases inherent in the dataset, yet we believe that this conclusion is valid based on the seasonal overlap of high densities of humpback whales and vessels and an increasing whale population trend in southeastern Alaska.

4.1. Reporting Biases. Although we attempted to capture all whale-vessel collisions throughout Alaska, the number we report here represents a minimum level of occurrence due to under-reporting of witnessed collisions and the significant challenges involved in investigating cause of death in whale mortalities in a large and remote state. We know that under-reporting of witnessed collisions occurs; for example, a survey of recreational boaters in southeastern Alaska documented that at least three out of four whalevessel collisions in this region were not reported (J. Straley, pers. comm.), and similar rates of under-reporting have been found among professional mariners in Hawaii [63]. This lack of reporting could be due to fear of possible repercussions or simple ignorance that collisions should be reported to NOAA. In 2009, NOAA implemented a tollfree Marine Mammal Stranding Hotline in Alaska, which increased public awareness about the existence of a stranding network and the agency's interest in collecting ship strike information and may have led to an increase in reports in recent years. One only has to engage in casual conversation with nearly any Alaskan boater to hear anecdotal stories of whale strikes that happened to them or someone they know. Most of these reports lack so many critical details such as vessel speed, location, and the fate of whale that although they would contribute to a better understanding of the true frequency of whale-vessel collisions, they might not advance our knowledge of the specific factors leading to collisions or their outcomes.

We documented collisions with seven of the 14 whale species known to occur in Alaska, with $86 \%$ of the reports involving humpback whales and none involving bowhead, minke, blue, sei, North Pacific right, Baird's beaked, or killer whales. We recognize that the records compiled here may be biased towards humpback whales because the authors are based in southeastern Alaska; however, the overwhelming number of live and dead reports involving humpback whales indicates that they are the most heavily impacted species, at least in terms of absolute numbers. The seasonal trend in collisions, with $91 \%$ of reports occurring in May through September, is not surprising because these are the months when humpback whales, which migrate in winter to lower latitudes, are most common in Alaska. The number of humpback whales that are known to have died from collisions in Alaska $(n=17)$ is much higher than in Washington from 1980-2006 $(n=1)$ [18] or British Columbia from 1995-2007 $(n=0)$ [64], despite both areas being important summer habitat for this species. The reason for this difference is unknown, but Douglas et al. [18] were surprised by the virtual absence of dead ship-struck humpback whales in Washington.

When a dead whale is reported in Alaska, there are limited resources and personnel to respond and conduct a 


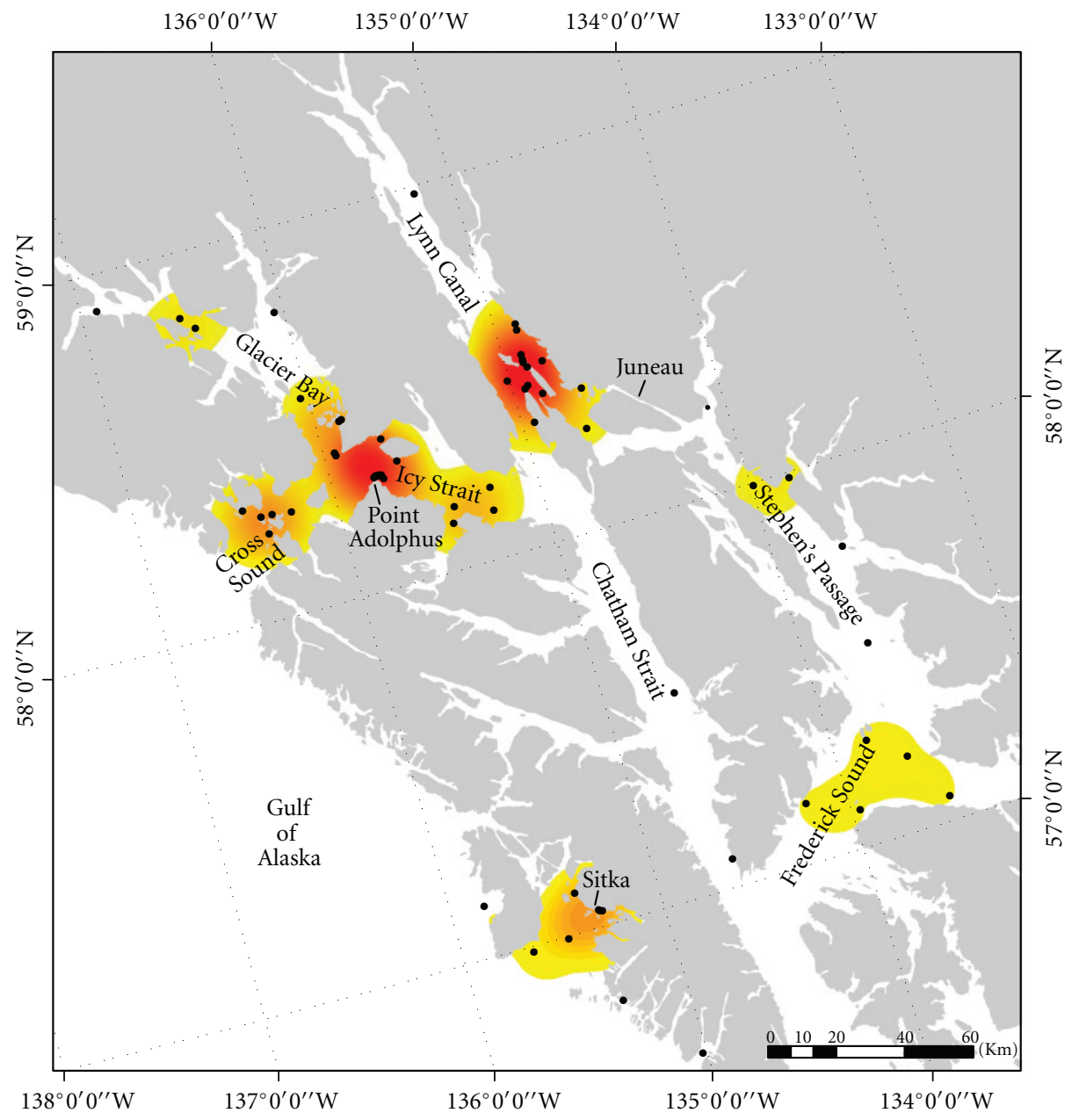

FIGURE 2: Whale-vessel collision hotspots in southeastern Alaska based on kernel density estimation. Yellow indicates moderate collision risk and red indicates higher collision risk. The locations of the collision reports used to create the map are displayed.

necropsy. Whether a necropsy is pursued or not depends on a variety of factors, including the condition of the carcass (ranging from fresh to skeletal), location and accessibility, safety, weather, available expertise, and whether the carcass is secured (such that it will not be washed away by the tide before a team can respond). Priority may be given to species listed under the ESA, species which are rarely encountered or for which little data exists (i.e., beaked whales), or incidents where there is a likelihood of human interaction (e.g., suspected ship strike, entanglement, shooting, etc.).

We were surprised to find so few collisions with fin whales $(n=3)$ given their abundance and widespread distribution in many parts of Alaska [28], especially compared to other studies, which have found them to be the most common species struck by vessels $[8,9,18]$. One reason so few fin whale collisions were observed is that fin whales are rare in the inside waters of southeastern Alaska frequented by vessels and occur more commonly offshore where a dead whale is less likely to be noticed. Collisions with gray whales $(n=1)$, sperm whales $(n=1)$, and killer whales $(n=0)$ were also rare compared to trends documented elsewhere $[8,18,64]$.
Although vessel collisions with beaked whales have been documented in other areas $[15,17,65]$, we were surprised to find three fatal strikes involving two Cuvier's beaked whales and one Stejneger's beaked whale because these species are observed rarely and typically inhabit offshore waters $[27,28]$.

We acknowledge several geographic biases in the records we compiled. The records are likely biased towards southeastern Alaska and there is a statewide bias towards human population centers (e.g., Juneau, Anchorage, Seward, and Kodiak) where there are more observers on the water. However, this goes hand-in-hand with more vessels on the water, so these areas probably do have a higher collision risk. Our dataset, like other ship strike datasets [9], is biased towards species that inhabit near shore waters, such as humpback whales, because carcasses of near shore species are more likely to be found (and subsequently examined) compared to offshore species. Furthermore, carcasses reported floating far offshore are unlikely candidates for towing to shore for necropsies given the long distances involved. In addition, whales that die offshore in water depths greater than $1,000 \mathrm{~m}$ may not float to the surface because the hydrostatic pressure at these 
depths limits the generation of buoyant decomposition gases [60]. There is generally more vessel traffic in near shore areas compared to offshore areas, which likely puts near shore species at a higher risk for collisions. We propose that a better understanding of the geographic extent of ship strikes in Alaska could be obtained by an effort to actively solicit information about past events from resource managers, law enforcement officers, the media, and the maritime community throughout the state. Maintaining NOAA's current focus on systematic data collection about ship strikes as they occur will also help facilitate equal representation of all parts of Alaska.

4.2. Ship Strike Confidence Categories. We recommend that the standardized system we developed to classify collision records into four confidence categories (definite strike, probable strike, possible strike, and rejected report), or a similar detailed system, be universally adopted to reduce uncertainty in interpreting ship strike data. Other investigators have employed similar tiered classification systems for dead whales with evidence of ship strike injuries (e.g., [10, 13, $15,16,18]$ ); however, our definitions contain a higher level of detail which we feel makes our approach more useful as a classification tool. Also, unlike other classification systems, ours includes criteria for classifying eyewitness collision reports. We recognize that our definitions err on the side of classifying strikes as definite when it is possible that some of these collisions occurred postmortem; however, we surmise that postmortem strikes of large whales are unlikely and consequently rare, given that floating carcasses are, in most cases, significantly bloated and therefore highly visible to the naked eye and radar ([15]; F. Gulland, pers. comm.). To rule out misclassifying postmortem collisions, we recommend that whenever possible, samples from stranded whales be collected and analyzed using histochemical techniques that can detect fat emboli diagnostic of ante mortem bone fractures and severe soft-tissue damage $[66,67]$.

We acknowledge that including possible and probable strikes in our analyses positively biased the number of ship strike records; however, like Van Waerebeek et al. [15], we chose to include these reports in our analysis because (a) we are trying to quantify a problem that we know is under-reported and (b) we feel that the confidence codes are generally conservative, meaning that the majority of the probable and possible strikes are likely to have been genuine collisions but incomplete followup and/or necropsies precluded classifying many of them as definite strikes.

Along with a standardized system to evaluate the level of certainty associated with individual collision reports, we also recommend that a universal standardized reporting form for collisions witnessed at sea would improve the quality of ship strike data by reducing the number of reports lacking key information such as vessel size and speed at the time of the collision. An outreach campaign to the public and to the resource protection agency personnel likely to respond to reported collisions will help ensure systematic reporting of the salient details of collisions. Currently, the
NOAA National Marine Mammal Stranding Database does not accept ship strike records, thus recording and cataloguing methods vary among NOAA regions across the country. Regions typically record collision reports on a general marine mammal stranding reporting form rather than using a specialized ship strike reporting form that prompts for key details. The latter approach is needed both nationally and internationally to ensure more systematic documentation of collisions and their outcomes.

4.3. Sex and Age Class of Struck Whales. We did not detect any difference in the collision risk for male versus female whales, but did find that calves and juveniles appear to be at higher risk of collisions than adult whales, which is consistent with other studies $[3,7,8,13,14,17,18]$. Our age class data are biased towards dead whales; therefore, it is unknown if young animals are overall more likely than adults to be struck (based on differences in their behavior, sightability, or other factors). It is also plausible that young animals are more likely to die from collisions because of their smaller body size.

4.4. Vessel Characteristics. All types and sizes of vessels collided with whales; however, small $(<15 \mathrm{~m})$ recreational vessels were the most common. This result contrasts with other studies that have concluded that small vessels are less likely than larger vessels to strike whales [8]. We found more private recreational vessel strikes and fewer commercial recreational vessel strikes than in Hawaii, where the majority of recorded collisions with humpback whales involved commercial whale watch vessels [14], but this result might be biased by different numbers of private versus commercial whale watch vessels in the two areas. The number of large vessels that we documented is presumably an underestimate because compared to smaller vessels, the crews of large vessels may be less likely to see collisions when they occur due to limited visibility around their bows, and the impact of a collision is less likely to be felt in larger vessels [8]. Undetected collisions with large vessels presumably account for some of the 22 cases where dead whales were found but no collision was reported. Alternatively, these collisions may have been witnessed but not reported. We recognize that the majority of records were based on witnessed collisions and that our conclusions regarding the types of vessels that hit whales are likely to be biased by different reporting and detection rates between vessel types. For example, some user groups may be more wary of reporting collisions to federal officials, and overall some user groups are more aware than others that collisions should be reported. For instance, in recent years, there has been a high level of awareness in the Alaska cruise ship industry about whale collision avoidance and reporting, but other user groups may not be as aware of the issue, leading to under-reporting.

It is notable that all 15 stationary vessels that were struck by humpback whales were drifting with their engine off or anchored. This suggests that the whales did not detect the vessels and that being in a silent vessel may increase the risk of a collision. Further evidence comes from a study of sailing vessel collisions with cetaceans, which found that $79 \%$ 
of collisions occurred when the vessels were under sail, as opposed to motoring [19]. Many boaters erroneously assume that whales are aware of their presence and location at all times. Increasing public outreach and education programs that emphasize that sperm whales are the only large whale species that uses echolocation could be beneficial in reducing collision risk.

4.5. Fate of Whales. Our data support previous findings that collisions are more likely to be lethal when they involve large ships and higher vessel speeds $[8,37]$. In the three mortalities where both vessel length and speed were known, the ships ranged from $216-243 \mathrm{~m}$ in length and were traveling $12-19 \mathrm{kn}$. Four other mortalities involved 190 $294 \mathrm{~m}$ ships traveling at unknown speeds. In addition to these seven mortalities, there were eight more dead whales whose massive injuries (e.g., fractured skulls) indicate that they were likely struck by large ships in collisions that were either not detected or witnessed but not reported. Conversely, four of the five cases in which struck humpback whales were known to have survived provide evidence that collisions with smaller, slower moving vessels are less likely to inflict serious or fatal injuries $[8,37]$. We know of at least 23 other humpback whales in southeastern Alaska that have survived collisions based on live sightings of 15 different whales with healed propeller wounds and eight whales with deep gashes and other wounds that appear to be from vessel collisions (NPS, UAS, NOAA, and Alaska Whale Foundation unpublished data). The vessel types, sizes, and speeds involved in these nonfatal collisions are unknown, but all of the propeller wounds appear to be from relatively small vessels based on the size and close spacing of the propeller scars.

The majority (80\%) of the collision records were based on strikes witnessed at sea, with the fate of the whale unknown in most $(72 \%)$ cases. However, over half (49\%) of the witnessed collisions occurred at vessel speeds $\geq 12 \mathrm{kn}$, and therefore some of these collisions may have been fatal, though the smaller size of most of the vessels presumably means that lethal collisions were less likely $[8,37]$. We found that vessel operators are often exceeding a "slow, safe speed" near humpback whales as required in Alaska [24] and that overall, vessels engaged in fast travel are at a greater risk of striking a whale. In the majority of cases, the collisions were accidental, with little or no time for evasive action. In a few cases $(n=10)$, vessel operators reported decelerating just prior to hitting the whale.

4.5.1. Mortalities. We found blunt trauma injuries (e.g., broken bones and a focal area of hemorrhaging) to be more than three times as common as sharp trauma injuries (e.g., propeller wounds) in whales that died from ship strikes in Alaska, whereas propeller injuries dominate among dead ship struck right whales along the US Atlantic and South African coasts [8] and gray whales in Washington [18]. Blunt trauma injuries were prevalent in ship struck balaenopterids examined in Washington [18] and in ship struck fin, blue, and sei whales along the US Atlantic and French coasts
[8]. Models indicate that whales at the water's surface are more likely to be hit by the bows of ships than whales submerged near the surface, which are more likely to suffer propeller strikes [36]. The majority (12 of 16) of the blunt trauma injuries in our sample were sustained by humpback whales. Humpback whales in Alaska typically make short, shallow dives [68] and spend a relatively high proportion of their time feeding, socializing, and resting at the surface (NPS unpublished data). This behavior pattern may make humpbacks more susceptible to bow strikes than propeller strikes, explaining why we found more blunt trauma injuries than sharp trauma injuries. In contrast, North Atlantic right whales spend the majority of their time submerged $0.5-2.5 \mathrm{~m}$ below the water's surface, which may explain why vessel collisions in general, and propeller injuries in particular, are so common in this species [69]. Douglas et al. [18] proposed two other possible explanations for the greater percentage of blunt traumas found in some species: (1) deep propeller wounds may open the body cavity and make the whale more likely to sink and not be recovered; (2) bow-caught whales (i.e., blunt trauma cases) are more likely to be transported to coastal waters where they can be recovered and examined. Both of these hypotheses may apply to our observations, but neither fully explains our findings. Note that in our dataset, 15 of the 16 whales with blunt trauma injuries were found floating or beach-cast, not bow-caught. However, some of these whales may have been bow-caught originally but then slipped off after the ships slowed down or stopped. Ships displacing 1600 or more gross tons are required to test their forward/astern propulsion within 12 hours of entering or getting underway in US waters [70], which could increase the chances of a bow-caught whale slipping off before it is detected.

A total of five dead whales were reported caught on the bulbous bows of large ships (three humpback whales, one fin whale, and one unidentified large baleen whale that appeared to be a fin, blue, or sei whale). Previously, stocky whale species such as humpback whales were not thought to be susceptible to being pinned to the bows of ships compared to longer, sleeker rorquals such as fin whales [8]. This conclusion was based on a single known case from Alaska of a humpback whale draped over a cruise ship's bulbous bow, and this whale slipped off the bow and sank when the ship slowed down $[8,71]$. A second case, reported to have occurred in Alaska in 2006 and cited by Van Waerebeek et al. [15], was misidentified in the media as a bow-caught humpback whale, but this was actually a fin whale [72]. In addition to the single bow-caught humpback whale case already reported in Laist et al. [8], we documented two new verified cases in which humpback whales were caught on the bows of ships. In both cases, the whales did not slip off when the ships stopped; in fact, in one case, it was difficult to dislodge the whale from the bow [61].

The 25 whales that we concluded had died from ship strikes from 1978-2011 represent the minimal number of whale mortalities from ship strikes in Alaska during this time period. Over the same time span, 516 large whales (i.e., baleen whales and sperm whales) were reported dead in Alaska (NOAA Alaska Region Stranding Database 
unpublished data). Thirty-two (6\%) of these carcasses were necropsied, with 13 of the whales classified as ship strikes in this study. Excluding two bow-caught whales (because they are not representative of the typical floating or beach-cast dead whale), 37\% (11 of 30) of the large whales necropsied in Alaska since 1978 have died from ship strikes. Similar high rates of ship strike mortalities have been found along the U.S. East Coast in some whale species (e.g., one-third of stranded northern right whales and fin whales) [8]. It is unknown how many more dead sank whales in Alaska were scavenged, floated offshore, and/or sunk without being located, but considering the remoteness of the state's coastline and offshore areas, 516 dead whales presumably represents a small fraction of the true number of dead whales over this 34-year period. Studies in the Gulf of Mexico suggest that on average, only $2 \%$ (range $0-6.2 \%$ ) of cetacean carcasses are recovered [73], and low detection rates (range $<1 \%-17 \%$ ) have also been documented in several other cetacean species in other areas [74-77]. The high rate of ship strike mortalities in Alaska, as indicated by the available necropsy data (37\%), suggests that many ship strike mortalities are likely going undetected in floating and beach-cast whales that are not examined.

In recent years, there has been improvement in the investigation of cause of death in whale stranding mortalities in Alaska, due to increased resources and expertise within the state, from sources such as the Prescott Marine Mammal Stranding Grant Program, the Alaska SeaLife Center, and additional veterinary support within the Alaska Marine Mammal Stranding Network. These improvements may explain some of the apparent increase in humpback whale ship strike mortalities over time. For example, 72\% (24 of 32) of the large whale necropsies conducted in Alaska since 1978 occurred between 2001 and 2011 (NOAA Alaska Region Stranding Database unpublished data), which reflects NOAA's increased commitment to necropsy whales over the past decade. Despite these improvements, limited resources and personnel, combined with the logistical challenges of responding to remote carcasses, continue to result in missed opportunities to investigate the cause of death in many whale strandings. While federal resource agencies in Alaska strive to promote and facilitate necropsies led by experienced teams, ideally veterinarians, to investigate cases of whale mortality, additional resources are recommended to increase capacity and infrastructure in necropsy response to improve cause of death investigations. For instance, establishing a statewide network of vessels that are available to tow floating whale carcasses to shore would reduce the number of missed opportunities for necropsies. In many cases, multiday necropsies may be needed to flense a carcass down to bone to examine the skeleton for fractures, especially because necropsy sites in Alaska are generally too remote for heavy equipment to assist with maneuvering large carcasses [1]. It may be beneficial to involve northern Alaska Eskimo subsistence whalers, who are highly skilled in flensing whales without the aid of machines, in large whale necropsy teams. Alternatively, returning to inspect carcasses over time to look for newly exposed broken bones may be helpful, although postmortem damage to bones on weather-beaten shores may confuse matters. Responding to whale strandings in Alaska will always be more challenging than in less remote areas where necropsy rates may be as high as 69\% [18], but continuing to increase efforts to perform complete necropsies (e.g., down to bone to examine for fractures, Table 1) using experienced teams focused on determining cause of death [1] is needed to allow for a more accurate determination of the rate of ship strike mortality in Alaska.

Performing full necropsies on ship struck whales is also important because they can reveal underlying factors such as disease, biotoxins, parasites, prior injuries, and entanglements in fishing gear that may have compromised a whale and predisposed it to being hit by a vessel $[8,15]$. Researchers investigating northern sea otter (Enhydra lutris) mortalities from vessel collisions in Alaska have found that many of the struck otters had underlying health issues such as bacterial infections and biotoxins that may have made them more susceptible to being hit (V. Gill, pers. comm.). In our sample, one adult humpback whale was found to have elevated saxitoxin levels that may have caused it to behave abnormally, which could have made it more vulnerable to being struck [61]. Systematic sample collection in all necropsies to test for an array of underlying factors is needed to gain a better understanding of how often these other stressors may be contributing to collisions. Recognizing that the pathology results from necropsies are often not available for weeks or months after the stranding, detecting the proximate and ultimate causes of vessel strikes will require stranding network personnel ensure that these results are systematically entered into the main record for each stranding in such a way that meta-analyses are possible. Storing these data in a usable fashion may require modifications to the national stranding database structure.

4.6. Human Toll and Property Damage from Collisions. The discovery that one-third of collisions resulted in some kind of human toll and/or property damage highlights that whalevessel collisions are a human safety issue. To date, there have been no confirmed human fatalities from collisions in Alaska, although in one of the reports we rejected, a $5 \mathrm{~m}$ skiff reportedly struck a gray whale, and the operator died after falling into the water [78]. The human fatality was confirmed but we could not confirm that the accident was caused by a collision with a whale. Threats to human safety posed by collisions have been documented elsewhere [8, 17, 19, 79], but the frequency of human injuries and property damage we documented may be positively biased because presumably these cases are more likely to be reported than other collisions. Increased attention to systematic documentation of human injuries and/or property damage in all collision reports is needed to allow for a more quantitative assessment of the problem. Regardless, the number of documented incidents indicates that boaters in Alaska, especially those operating small open vessels where the likelihood of being thrown into the water from a collision is high, would benefit from public outreach and education programs that raise awareness of the risks posed by collisions and how these risks can be minimized (e.g., slow down, keep a sharp lookout for whales, always wear a life-jacket, etc.). 
4.7. Management Recommendations. As we have shown in our analyses, the problem of whale-vessel collisions is clearly one that can be detrimental to whales and humans. Conversely, avoiding whale-vessel collisions is mutually beneficial, but the challenge is to understand how best to reach and advise each user group, given the tangle of human factors that influence vessel operators' decisions. These factors include, but are not limited to: economics, convenience, knowledge and tolerance of risk, and whether they are professional or recreational vessel operators. For the professional mariner, the recently published International Whaling Commission and International Maritime Organization collision avoidance leaflet [80] gives practical advice (e.g., pay attention, avoid areas where you know there are whales, and slow down) in an appealing and respectful format. Available on the internet in six languages, this leaflet also highlights the importance of reporting collisions to foster an understanding that will help avoid future incidents. Wide distribution of this leaflet in the international maritime industry will highlight the issue and create an ongoing dialog on whale avoidance in the industry that seems likely to alleviate some collision risk.

For recreational boaters, we suggest that the most effective approach for raising awareness of the issue would occur in nonregulatory settings using contemporary modes of communication including social networking, to inform people how to avoid collisions, and the need to report incidents when they occur. A key message for operators of small boats in Alaska is that the likelihood of colliding with a whale is increasing, and that people can get hurt, costly vessel damage can occur and the whale can be injured or killed. Simple but specific preventive measures that encourage vigilance and the willingness to use slow speeds in highdensity whale areas should be made widely available in a sound-byte format that is easy to digest. Creating and distributing these messages is a step toward creating a culture where people understand the risks and will do what they can to avoid collisions with whales.

Collision hotspots (Figure 2) are areas that warrant special attention in the form of vessel speed limits, public service announcements, increased law enforcement presence or other measures. The map we created for this paper is the first regional look at the geography of collisions in Alaska, and may be a useful approach for analysis of other collision datasets outside Alaska. High-risk areas need to be closely examined and coupled with predictive modeling to assess areas where conservation action (e.g., vessel speed limits) may be targeted to prevent future vessel collisions with whales in Alaska. For example, a recommendation to reduce speed at night in known hotspot areas may be particularly relevant for large ships (such as cruise ships) which routinely transit at night. Commercial vessels may want to consider marketing "whale friendly" voyages by advertising and adhering to lowered speeds as part of their standard operations, along with increased care and attentiveness in hotspot areas. Reduced speeds have been used successfully in Glacier Bay National Park for many years (termed "whale waters"), where the park superintendent implements vessel course and speed restrictions in areas where whale concentrations have been detected [25]. Protective measures applied to relatively small areas with reliably high whale densities may yield a disproportionately large reduction in collision risk for humpback whales in southeastern Alaska and presumably impact fewer vessel operators compared to other mitigation measures [81]. As whale populations and vessel traffic continue to change throughout the state, improved data collection and validation of collision reports will enhance our understanding of collisions, with the ultimate goal of reducing the frequency of whale-vessel collisions in Alaska.

\section{Acknowledgments}

The authors gratefully acknowledge the many organizations and individuals who have reported and collected data on whale-vessel collisions over the years including members of the Alaska Marine Mammal Stranding Network; the US Coast Guard; NOAA Enforcement; the Alaska Department of Fish \& Game; the Alaska State Troopers; tour operators; vessel captains, pilots, and crew; harbormasters; fishermen; recreational boaters; Charles Jurasz; and C. Scott Baker. They thank John Sease, Linda Shaw, and Kaja Brix for developing the Alaska Marine Mammal Stranding Network with limited resources; Mary Sternfeld, who shepherded the NOAA Alaska Region Stranding Database through its infancy; Doug DeMaster for initiating the first paper on this topic for the IWC in 2007 and for providing valuable comments on this paper. Special credit goes to Dr. Frances Gulland from The Marine Mammal Center for leading necropsies in Alaska, training local responders in ship strike necropsy methods, and contributing her expertise to this paper. They extend sincere thanks to the Alaskan marine mammal veterinarians (Dr. Kathy Burek, Dr. Rachel Dziuba, Dr. Carrie Goertz, Dr. Kate Savage, and Dr. Pam Tuomi) and volunteers who have conducted and participated in whale necropsies. They are indebted to Jen Cedarleaf (UAS) for her expert fluke matching skills which allowed them to identify several of the dead humpback whales in this study. They thank John Moran (NOAA), Fred Sharpe (Alaska Whale Foundation), and Erin Falcone (Cascadia Research Collective) for sharing photos of live whales with collision injuries. They are grateful to David Mattila (IWC), Ed Lyman (NOAA), and Jerry Dzugan (Alaska Marine Safety Education Association) for contributing to and supporting this study. They thank Whitney Rapp and Greg Ambrose for their help developing the hotspot map. They thank two anonymous reviewers for their valuable comments on this paper. Necropsies on endangered whales were conducted under National Marine Fisheries Service (NMFS) permits 932-1489 and 9321905.

\section{Endnotes}

1. Listed as endangered under the ESA.

2. Listed as endangered under the ESA (Cook Inlet stock only). 


\section{References}

[1] W. McLellan, S. Rommel, M. Moore, and D. A. Pabst, "Right whale necropsy protocol," Final Report to NOAA Fisheries for Contract \#40AANF112525, 2004.

[2] J. George, L. Philo, K. Hazard, D. Withrow, G. Carroll, and R. Suydam, "Frequency of killer whale (Orcinus orca) attacks and ship collisions based on scarring on bowhead whales (Balaena mysticetus) of the Bering-Chukchi-Beaufort Seas stock," Arctic, vol. 47, no. 4, pp. 247-255, 1994.

[3] D. N. Wiley, R. A. Asmutis, T. D. Pitchford, and D. P. Gannon, "Stranding and mortality of humpback whales, Megaptera novaeangliae, in the mid-Atlantic and southeast United States, 1985-1992," Fishery Bulletin, vol. 93, pp. 196-205, 1995.

[4] I. N. Visser, "Propeller scars on and known home range of two orca (Orcinus orca) in New Zealand waters," New Zealand Journal of Marine and Freshwater Research, vol. 33, pp. 635642, 1999.

[5] P. B. Best, V. M. Peddemors, V. G. Cockcroft, and N. Rice, "Mortalities of right whales and related anthropogenic factors in South African waters, 1963-1998," Journal of Cetacean Research and Management, vol. 2, no. 2, pp. 171-176, 2001.

[6] J. Capella, L. Flórez-González, and P. Falk, "Mortality and anthropogenic harassment of humpback whales along the Pacific coast of Colombia," Memoirs of the Queensland Museum, vol. 47, no. 2, pp. 547-553, 2001.

[7] A. R. Knowlton and S. D. Kraus, "Mortality and serious injury of northern right whales (Eubalaena glacialis) in the western North Atlantic Ocean," Journal of Cetacean Research and Management, vol. 2, pp. 1-15, 2001.

[8] D. W. Laist, A. R. Knowlton, J. G. Mead, A. S. Collet, and M. Podesta, "Collisions between ships and whales," Marine Mammal Science, vol. 17, no. 1, pp. 35-75, 2001.

[9] A. S. Jensen and G. K. Silber, "Large whale ship strike database," NOAA Technical Memorandum NMFS-OPR-25, U.S. Department of Commerce, Washington, DC, USA, 2003.

[10] M. J. Moore, A. R. Knowlton, S. D. Kraus, W. A. McLellan, and R. K. Bonde, "Morphometry, gross morphology and available histopathology in North Atlantic right whale (Eubalaena glacialis) mortalities (1970-2002)," Journal of Cetacean Research and Management, vol. 6, no. 3, pp. 199-214, 2004.

[11] M. Weinrich, "A review of worldwide collisions between whales and fast ferries," Paper SC/56/BC9, International Whaling Commission Scientific Committee, Cambridge, UK, 2005, IWC Secretariat, http://www.iwcoffice.org/publications/ doclist.htm

[12] M. Weinrich, "A review of collisions between whales and whale watch boats," Paper SC/57/WW8, International Whaling Commission Scientific Committee, Cambridge, UK, 2005, IWC Secretariat, http://www.iwcoffice.org/publications/ doclist.htm.

[13] S. Panigada, G. Pesante, M. Zanardelli, F. Capoulade, A. Gannier, and M. T. Weinrich, "Mediterranean fin whales at risk from fatal ship strikes," Marine Pollution Bulletin, vol. 52, no. 10, pp. 1287-1298, 2006.

[14] M. O. Lammers, A. A. Pack, and L. Davis, "Trends in whale/ vessel collisions in Hawaiian waters," Paper SC/59/BC14, International Whaling Commission Scientific Committee, Cambridge, UK, 2007, IWC Secretariat, http://www.iwcoffice.org/publications/doclist.htm.

[15] K. Van Waerebeek, A. N. Baker, F. Félix et al., "Vessel collisions with small cetaceans worldwide and with large whales in the Southern Hemisphere, an initial assessment," Latin American Journal of Aquatic Mammals, vol. 6, no. 1, pp. 43-69, 2007.
[16] S. Behrens and R. Constantine, "Large whale and vessel collisions in northern New Zealand," Paper SC/60/BC9, International Whaling Commission Scientific Committee, Cambridge, UK, 2008, IWC Secretariat, http://www.iwcoffice.org/ publications/doclist.htm.

[17] M. Carrillo and F. Ritter, "Increasing numbers of ship strikes in the Canary Islands: proposals for immediate action to reduce risk of vessel-whale collisions," Journal of Cetacean Research and Management, vol. 11, no. 2, pp. 131-138, 2010.

[18] A. B. Douglas, J. Calambokidis, S. Raverty, S. J. Jeffries, D. M. Lambourn, and S. A. Norman, "Incidence of ship strikes of large whales in Washington State," Journal of the Marine Biological Association of the United Kingdom, vol. 88, pp. 11211132, 2008.

[19] F. Ritter, "Collisions of sailing vessels with cetaceans worldwide: first insights into a seemingly growing problem," Paper SC/61/BC1, International Whaling Commission Scientific Committee, Cambridge, UK, 2009, IWC Secretariat, http://www.iwcoffice.org/publications/doclist.htm.

[20] M. Berman-Kowalewski, F. M. Gulland, S. Wilkin et al., "Association between blue whale (Balaenoptera musculus) mortality and ship strikes along the California coast," Aquatic Mammals, vol. 36, no. 1, pp. 59-66, 2010.

[21] U.S. Marine Mammal Protection Act of 1972, as amended (16 U.S. Code 1361 et seq).

[22] K. van Waerebeek and R. Leaper, "Report from the IWC vessel strike data standardisation group," Paper SC/59/BC12, International Whaling Commission Scientific Committee, Cambridge, UK, 2007, IWC Secretariat, http://www.iwcoffice.org/publications/doclist.htm.

[23] "Definitions," Code of Federal Regulations, Title 50, Part 216.3.

[24] "Special prohibitions for endangered marine mammals," Code of Federal Regulations, Title 50, Part 224.103.

[25] Special Regulations-Glacier Bay National Park and Preserve, Code of Federal Regulations, Title 36, Part 13, Subpart N.

[26] NOAA Alaska Region Stranding Record \#2007068, (unpublished, available from National Marine Fisheries Service, Protected Resources Division, PO Box 21668, Juneau, AK, 99802).

[27] K. Wynne, Guide to Marine Mammals of Alaska, Alaska Sea Grant College Program, Fairbanks, Alaska, USA, 3rd edition, 2007.

[28] B. M. Allen and R. P. Angliss, "Alaska marine mammal stock assessments 2010," NOAA Technical Memorandum NMFSAFSC-223, U.S. Department of Commerce, Washington, DC, USA, 2011.

[29] J. C. George, J. Zeh, R. Suydam, and C. Clark, "Abundance and population trend (1978-2001) of western arctic bowhead whales surveyed near Barrow, Alaska," Marine Mammal Science, vol. 20, no. 4, pp. 755-773, 2004.

[30] A. N. Zerbini, J. M. Waite, J. L. Laake, and P. R. Wade, "Abundance, trends and distribution of baleen whales off western Alaska and the central Aleutian Islands," Deep-Sea Research I, vol. 53, no. 11, pp. 1772-1790, 2006.

[31] J. Calambokidis, E. A. Falcone, T. J. Quinn et al., "SPLASH: structure of populations, levels of abundance and status of humpback whales in the North Pacific," Final Report for Contract AB133F-03-RP-00078, U.S. Department of Commerce, Washington, DC, USA, 2008.

[32] A. E. Punt and P. R. Wade, "Population status of the eastern North Pacific stock of gray whales in 2009," NOAA Technical Memorandum NMFS-AFSC-207, U.S. Department of Commerce, Washington, DC, USA, 2010. 
[33] P. R. Wade, A. Kennedy, R. LeDuc et al., "The world's smallest whale population?” Biology Letters, vol. 7, no. 1, pp. 83-85, 2011.

[34] P. R. Wade, A. de Robertis, K. R. Hough et al., "Rare detections of North Pacific right whales in the Gulf of Alaska, with observations of their potential prey," Endangered Species Research, vol. 13, no. 2, pp. 99-109, 2011.

[35] S. M. Gende, A. N. Hendrix, K. R. Harris, B. Eichenlaub, J. Nielsen, and S. Pyare, "A Bayesian approach for understanding the role of ship speed in whale-ship encounters," Ecological Applications, vol. 21, no. 6, pp. 2232-2240, 2011.

[36] G. K. Silber, J. Slutsky, and S. Bettridge, "Hydrodynamics of a ship/whale collision," Journal of Experimental Marine Biology and Ecology, vol. 391, no. 1-2, pp. 10-19, 2010.

[37] A. S. M. Vanderlaan and C. T. Taggart, "Vessel collisions with whales: the probability of lethal injury based on vessel speed," Marine Mammal Science, vol. 23, no. 1, pp. 144-156, 2007.

[38] C. M. Gabriele, A. Jensen, J. L. Neilson, and J. M. Straley, "Preliminary summary of reported whale-vessel collisions in Alaskan waters: 1978-2006," Paper SC/59/BC16, International Whaling Commission Scientific Committee, Cambridge, UK, 2007, IWC Secretariat, http://www. iwcoffice.org/publications/doclist.htm.

[39] A. S. Jensen, J. L. Neilson, C. M. Gabriele, and J. M. Straley, "Summary of reported whale-vessel collisions in Alaskan waters: 1978-2008," The Alaska Marine Science Symposium, 2010.

[40] S. T. Zimmerman, "A history of marine mammal stranding networks in Alaska, with notes on the distribution of the most commonly stranded cetacean species, 1975-1987," in Marine Mammal Strandings in the United States-Proceedings of the 2nd Marine Mammal Stranding Workshop, J. E. Reynolds and D. K. Odell, Eds., pp. 43-53, National Oceanic and Atmospheric Administration Technical Report 98, Washington, DC, USA, 1991.

[41] H. Omura, K. Fujino, and S. Kimura, "Beaked whale Berardius bairdi of Japan, with notes on Ziphius cavirostris," The Scientific Reports of the Whales Research Institute 10, 1955.

[42] C. Lockyer, "The age at sexual maturity of the southern fin whale (Balaenoptera physalus) using annual layer counts in the ear plug," Journal du Conseil, Conseil International pour l'Exploration de la Mer, vol. 34, pp. 276-294, 1972.

[43] J. G. Mead, "Survey of reproductive data for the beaked whales (Ziphiidae)," Reports of the International Whaling Commission, no. 6, pp. 91-96, 1984.

[44] J. L. Sumich and J. T. Harvey, "Juvenile mortality in gray whales (Eschrichtius robustus)," Journal of Mammalogy, vol. 67, pp. 179-182, 1986.

[45] B. M. Allen, R. L. Brownell, and J. G. Mead, "Species review of Cuvier's beaked whale, Ziphius cavirostris," Paper SC/63/SM17, International Whaling Commission Scientific Committee, Cambridge, UK, 2011, IWC Secretariat, http:// www.iwcoffice.org/publications/doclist.htm.

[46] P. J. Clapham, "Age at attainment of sexual maturity of humpback whales, Megaptera novaeangliae," Canadian Journal of Zoology, vol. 70, no. 7, pp. 1470-1472, 1992.

[47] R. G. Chittleborough, "The breeding cycle of the female humpback whale, Megaptera nodosa (Bonnaterre)," Australian Journal of Marine \& Freshwater Research, vol. 9, no. 1, pp. 1-18, 1958.

[48] P. J. Clapham, S. E. Wetmore, T. D. Smith, and J. G. Mead, "Length at birth and at independence in humpback whales," Journal of Cetacean Research and Management, vol. 1, no. 2, pp. 141-146, 1999.
[49] J. M. Straley, Seasonal characteristics of humpback whales (Megaptera novaeangliae) in southeastern Alaska, M.S. thesis, University of Alaska, Fairbanks, Alaska, USA, 1994.

[50] D. W. Rice, "Progress report on biological studies of the larger cetaceans in the waters off California," Norsk HvalfangstTidende, vol. 52, no. 7, pp. 181-187, 1963.

[51] NOAA Alaska Region Stranding Record \#2005003, (unpublished, available from National Marine Fisheries Service, Protected Resources Division, PO Box 21668, Juneau, AK, 99802).

[52] C. M. Gabriele, J. M. Straley, S. A. Mizroch et al., "Estimating the mortality rate of humpback whale calves in the central North Pacific Ocean," Canadian Journal of Zoology, vol. 79, no. 4, pp. 589-600, 2001.

[53] U.S. Coast Guard and United States Coast Guard Maritime Information eXchange, "Port State Information eXchange," http://cgmix.uscg.mil/PSIX/PSIXSearch.aspx/2011.

[54] R. Campbell-Malone, S. G. Barco, P. Y. Daoust et al., "Gross and histologic evidence of sharp and blunt trauma in North Atlantic right whales (Eubalaena glacialis) killed by vessels," Journal of Zoo and Wildlife Medicine, vol. 39, no. 1, pp. 37-55, 2008.

[55] S. Barco and K. Touhey, "Handbook for recognizing, evaluating, and documenting human interaction in stranded cetaceans and pinnipeds," Report from the Virginia Aquarium Stranding Response Program and Cape Cod Stranding Network, 2006.

[56] NOAA Alaska Region Stranding Record \#1978050, (unpublished, available from National Marine Fisheries Service, Protected Resources Division, P.O. Box 21668, Juneau, AK, 99802)

[57] NOAA Alaska Region Stranding Record \#2008145, (unpublished, available from National Marine Fisheries Service, Protected Resources Division, P.O. Box 21668, Juneau, AK, 99802).

[58] NOAA Alaska Region Stranding Record \#2008031, (unpublished, available from National Marine Fisheries Service, Protected Resources Division, P.O. Box 21668, Juneau, AK, 99802).

[59] E. J. lijper, Whales and Dolphins, The University of Michigan Press, Ann Arbor, Mich, USA, 1978.

[60] P. A. Allison, C. R. Smith, H. Kukert, J. W. Deming, and B. A. Bennett, "Deep-water taphonomy of vertebrate carcasses: a whale skeleton in the bathyal Santa Catalina Basin," Paleobiology, vol. 17, no. 1, pp. 78-89, 1991.

[61] NOAA Alaska Region Stranding Record \#2010089, (unpublished, available from National Marine Fisheries Service, Protected Resources Division, P.O. Box 21668, Juneau, AK, 99802).

[62] A. N. Hendrix, J. Straley, C. Gabriele, and S. Gende, "Bayesian estimation of humpback whale (Megaptera novaeangliae) population abundance and movement patterns in Southeast Alaska," Canadian Journal of Fisheries and Aquatic Science. In press.

[63] International Whaling Commission and Agreement on the Conservation of Cetaceans in the Black Sea, Mediterranean Sea and Contiguous Atlantic Area, "Report of the joint IWC-ACCOBAMS workshop on reducing risk of collisions between vessels and cetaceans," Tech. Rep., International Whaling Commission and Agreement on the Conservation of Cetaceans in the Black Sea, Mediterranean Sea and Contiguous Atlantic Area, Beaulieu-sur-Mer, France, 2010.

[64] R. Williams and P. O’Hara, "Modelling ship strike risk to fin, humpback and killer whales in British Columbia, Canada," 
Journal of Cetacean Research and Management, vol. 11, no. 1, pp. 1-8, 2010.

[65] M. L. Dalebout, K. G. Russell, M. J. Little, and P. Ensor, "Observations of live Gray's beaked whales (Mesoplodon grayi) in Mahurangi Harbour, North Island, New Zealand, with a summary of at-sea sightings," Journal of the Royal Society of New Zealand, vol. 34, no. 4, Article ID R03012, pp. 347-356, 2004.

[66] A. Fernández, J. F. Edwards, F. Rodriguez et al., "Gas and fat embolic syndrome' involving a mass stranding of beaked whales (family Ziphiidae) exposed to anthropogenic sonar signals," Veterinary Pathology, vol. 42, no. 4, pp. 446-457, 2005.

[67] M. J. Shkrum and D. A. Ramsay, Forensic Pathology of Trauma: Common Problems for the Pathologist, Humana Press, Totowa, NJ, USA, 2007.

[68] W. F. Dolphin, "Ventilation and dive patterns of humpback whales, (Megaptera novaeangliae), on their Alaskan feeding grounds," Canadian Journal of Zoology, vol. 65, no. 1, pp. 8390, 1987.

[69] S. E. Parks, J. D. Warren, K. Stamieszkin, C. A. Mayo, and D. Wiley, "Dangerous dining: surface foraging of North Atlantic right whales increases risk of vessel collisions," Biology Letters, vol. 8, no. 1, pp. 57-60, 2012.

[70] “Tests before entering or getting underway," Code of Federal Regulations, Title 33, Part 164.25.

[71] NOAA Alaska Region Stranding Record \#1999095, (unpublished, available from National Marine Fisheries Service, Protected Resources Division, P.O. Box 21668, Juneau, AK, 99802).

[72] NOAA Alaska Region Stranding Record \#2006140, (unpublished, available from National Marine Fisheries Service, Protected Resources Division, P.O. Box 21668, Juneau, AK, 99802).

[73] R. Williams, S. Gero, L. Bejder et al., "Underestimating the damage: interpreting cetacean carcass recoveries in the context of the Deepwater Horizon/BP incident," Conservation Letters, vol. 4, no. 3, pp. 228-233, 2011.

[74] J. E. Heyning and M. E. Dahlheim, "Strandings and incidental takes of gray whales," Paper SC/A90/G2, International Whaling Commission Scientific Committee on the Assessment of Gray Whales, Cambridge, UK, 1990, IWC Secretariat, http://www.iwcoffice.org/publications/doclist.htm.

[75] S. D. Kraus, M. W. Brown, H. Caswell et al., "North Atlantic right whales in crisis," Science, vol. 309, no. 5734, pp. 561-562, 2005.

[76] J. E. Moore and A. J. Read, "A Bayesian uncertainty analysis of cetacean demography and bycatch mortality using age-atdeath data," Ecological Applications, vol. 18, no. 8, pp. 19141931, 2008.

[77] H. Peltier, W. Dabin, P. Daniel et al., "The significance of stranding data as indicators of cetacean populations at sea: modelling the drift of cetacean carcasses," Ecological Indicators, vol. 18, pp. 278-290, 2012.

[78] J. Empire, State and Local Briefly, 2000.

[79] R. de Stephanis and E. Urquiola, "Collisions between ships and cetaceans in Spain," Paper SC/58/BC5, International Whaling Commission Scientific Committee, Cambridge, UK, 2006, IWC Secretariat, http://www.iwcoffice.org/publications/ doclist.htm.

[80] Belgian Federal Public Service Health, Food Chain Security and Environment, "Whales: avoiding collisions prevents damage to ships, and injuries to passengers, crew and whales," http://iwcoffice.org/_documents/sci_com/shipstrikes/, 2011 English\%20whale\%20strike\%20folder.pdf, 2011.

[81] E. M. Chenoweth, C. M. Gabriele, and D. F. Hill, "Tidal influences on humpback whale habitat selection near headlands," Marine Ecology Progress Series, vol. 423, pp. 279-289, 2011. 

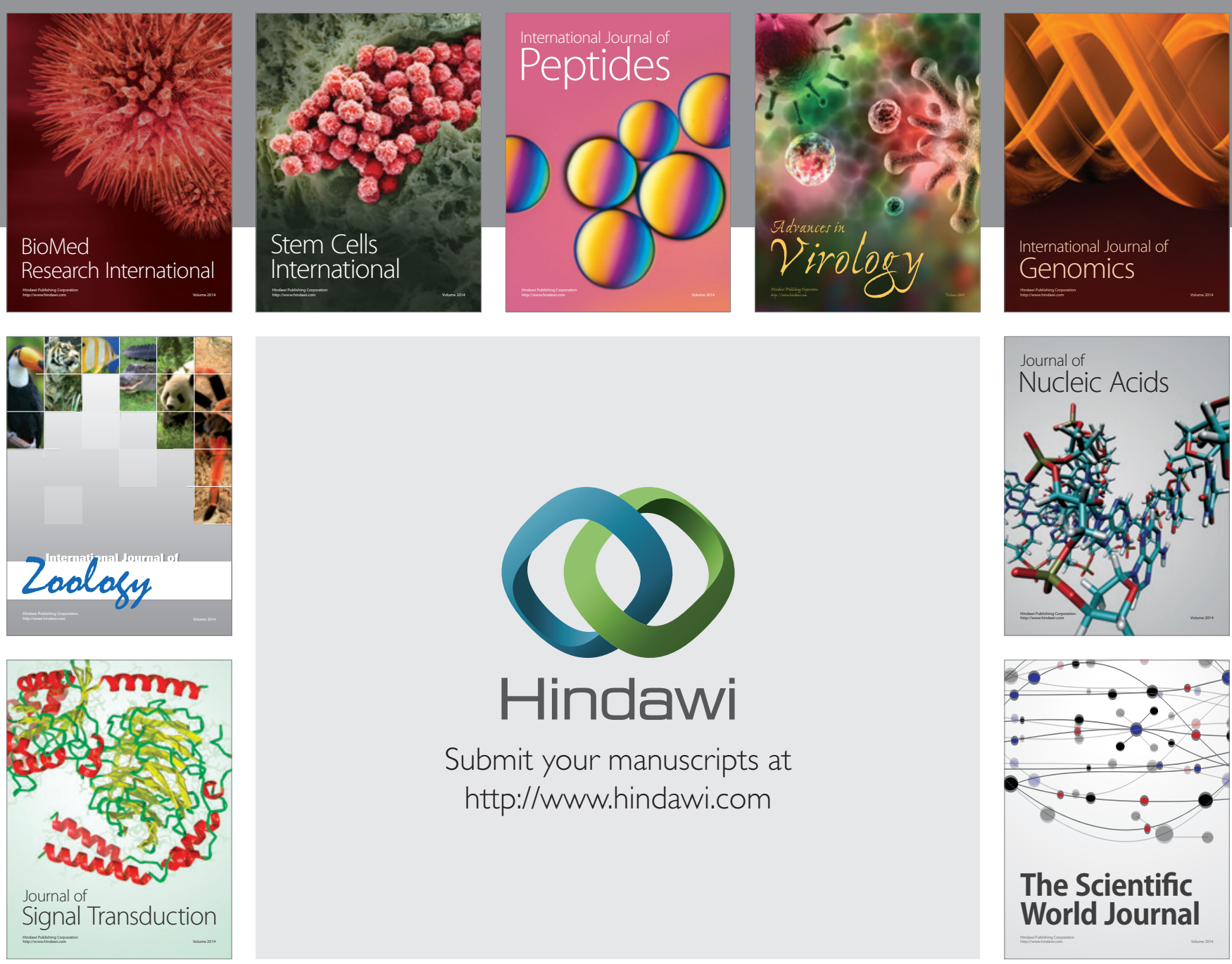

Submit your manuscripts at

http://www.hindawi.com
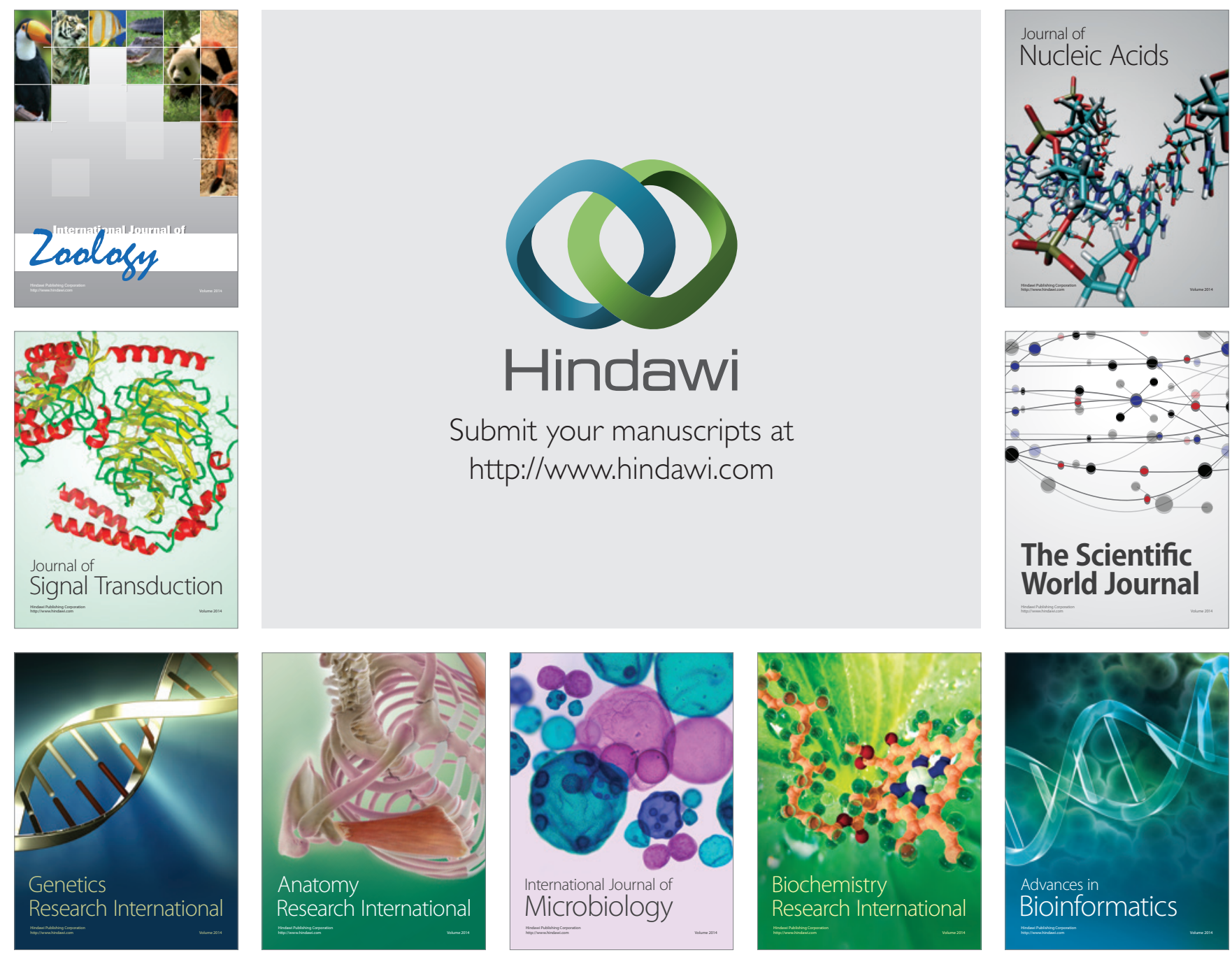

The Scientific World Journal
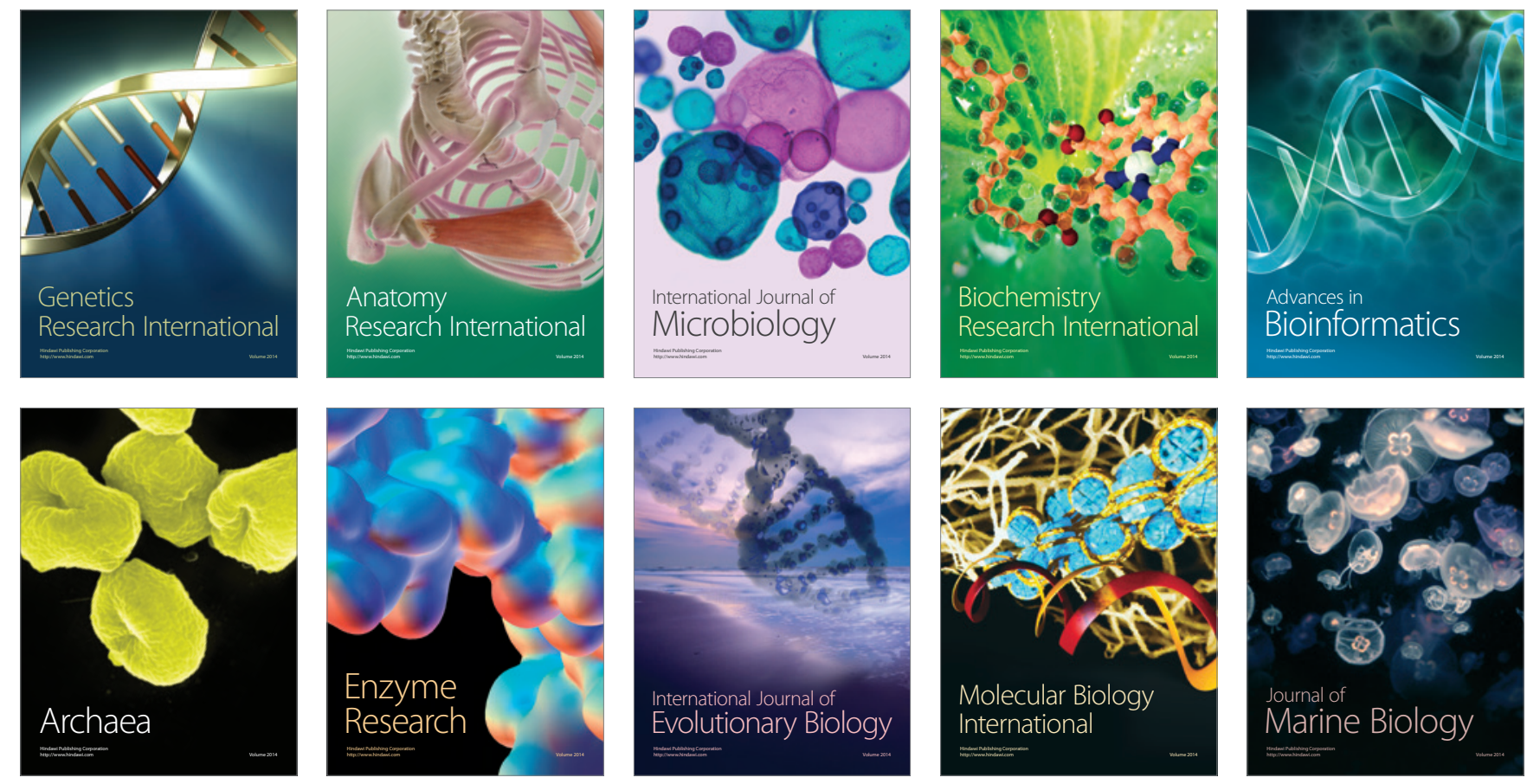